\title{
ARTICLES \\ IS IT “CHARITABLE” TO DISCRIMINATE?: THE NECESSARY TRANSFORMATION OF SECTION 501(C)(3) INTO THE GOLD STANDARD FOR CHARITIES
}

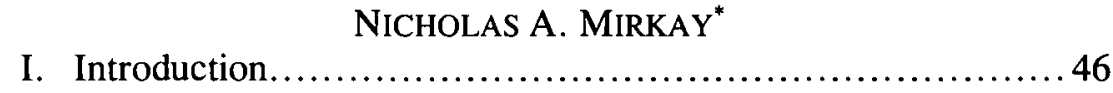

II. The Evolving Meaning of "Charitable" .....................53 53

A. What Is "Discrimination"? ...........................55 53

B. The Federal Income-Tax Exemption ...................54

C. The Statutory Impact of "Charitable" ..................56

D. The Public-Policy Doctrine's Impact on "Charitable" .....61

1. Bob Jones University v. United States................61

2. Critique of the Public-Policy Doctrine................65

E. Boy Scouts of America v. Dale: A Missed Opportunity to Clarify the Public-Policy Doctrine's Scope? .............6 68

III. Alternative Proposals for Combating Discrimination by Charitable Organizations ...................................72

A. The Public-Policy Doctrine: Clarification and Expanded Scope?

B. Expanding Civil-Rights Laws' Applicability to Charitable Organizations ................................74

1. An Overview of the Expansion Approach..............74

2. Critique of the Expansion Approach .................. 82

IV. Amendment of Section 501(c)(3) to Establish A Nondiscrimination Requirement for Tax Exemption ........... 83

A. The Nondiscrimination-Requirement Proposal ............84 84

B. Difficulties and Potential Criticisms ...................... 88

1. Constitutionality Issues............................ 88

2. The Negative Impact on Pluralism .................. 94

\footnotetext{
* Associate Professor of Law, Widener University School of Law, Wilmington, Delaware; J.D., University of Missouri-Columhia School of Law; LL.M., Georgetown University Law Center. Special thanks to Michelle Arnopol Cecil, Leandra Lederman, Roberta Mann, Paul Regan, and Serena Williams for their review and insightful comments. Thanks also to Erin Downing for her invaluahle research assistance, Kim Brombacher for her research and for creating the notion of equating tax-exempt status under section 501(c)(3) with a "social contract," Carol Perrupato for her indispensable secretarial assistance, and Alan Gardner for his love and support during the research and writing of this Article. Any remaining errors or omissions are mine alone.
} 
3. Applicability to Religious Organizations .95

a. Overview of the Religious Exemption ............. 95

b. Exception for a "Church" ...................... 100

4. Other Potential Issues ............................... 103

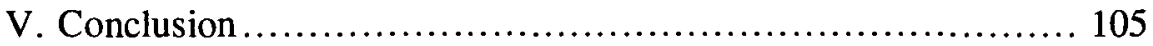

\section{INTRODUCTION}

With federal subsidies to tax-exempt charitable organizations ${ }^{1}$ estimated to be approximately $\$ 232$ billion for the fiscal years of 2007 to $2011,{ }^{2}$ the public benefit of these organizations is an increasingly hot topic for Congress, the Internal Revenue Service (IRS), and the entire nonprofit sector. Concerns over the hefty economic cost of supporting charitable organizations via the charitable-contributions deduction, the excessive compensation to nonprofit executives, the amount of charity care provided by nonprofit versus for-profit hospitals, and responsible corporate governance have led to a call for increased scrutiny and accountability of charitable organizations. ${ }^{3}$ Furthermore, the IRS's inquiries into the alleged political-campaign activities of charitable organizations surrounding the 2004 presidential election-most notably,

1. This Article uses the terms "charitable organization," "tax-exempt organization," and "exempt organization" interchangeably to refer to nonprofit organizations that qualify for, and have been granted, an exemption from federal income tax. See generally I.R.C. §501(c)(3) (2000). In addition, the terms "exemption" and "tax-exempt status" refer exclusively to federal income-tax law and do not imply exemption under other federal tax laws, or under state or local laws, unless otherwise indicated. For an explanation of the common practice of referring to all organizations exempt under section 501(c)(3) collectively as "charitable" organizations see infra notes 60-62 and accompanying text.

2. See Office of Mgmt. \& Budget, Executive Office of the President, BUdGet OF THE UNITED STATES Government: FisCAL YeAr 2007, at 291 tbl.19-2, available at http://www.whitehouse.gov/omb/budget/fy2007/pdf/spec.pdf (estimating tax expenditures for corporate and individual income taxes with respect to the deductibility of charitable contributions to charitable organizations).

3. See David L. Wolff \& Michael D. Rosenbaum, GAO Survey of Nonprofit Hospitals Latest Step in Congressional Investigation of Tax-Exempt Organizations, 52 EXEMPT ORG. TAX ReV. 265 (2006); Kurt Ritterpusch, Grassley to Seek More Charitable Reforms Including Executive Compensation Changes, DaILY TAX REP., Jan. 13, 2006, at G-1; Diane Freda, Sen. Grassley Queries Red Cross On Disaster Relief Role, CEO's Exit, DaILy TAX ReP., Jan. 3, 2006, at G-2; Steve Teske, House Tax Panel Chairman Says Exemption for Hospitals Becoming Difficult to Justify, DAILY TAX REP., May 27, 2005, at G-1; Steve Teske, Grassley Wants Nonprofit Hospitals To Account for Charity Care Activities, DaILY TAX REP., May 26, 2005, at G-6. 
the NAACP and the All Saints Episcopal Church in California ${ }^{4}$-are reviving the debate over the role of charitable organizations in our modern, politically divided society.

Amidst this heightened scrutiny of charitable organizations and their activities, the Independent Sector-a nonpartisan coalition of over 500 nonprofit organizations-convened the Panel on the Nonprofit Sector in late 2004 at the encouragement of the Senate Finance Committee. ${ }^{5}$ The Panel's mission was to provide recommendations to Congress "to improve the oversight and governance of charitable organizations." In a final report released on June 22, 2005, the Panel provided over 120 recommendations, including certain governance changes. ${ }^{7}$ State legislatures are also joining the burgeoning scrutiny and reform of charitable organizations, with several considering legislation to stop abusive practices and to improve overall transparency and accountability. ${ }^{8}$

Despite this recent focus on the transparency of charitable organizations and their activities, one recurring activity continues to fly under the radar of reformers: discrimination. Charitable organizations discriminate not only in the employment context, but more importantly in that of services or activities for which the government has granted a tax-exempt status-such as education. It has a variety of bases, including sexual orientation, marital status, and religious belief.

Boy Scouts of America v. Dale is perhaps the most renowned recent case involving discrimination by a charitable organization. 1n that case, a local council of the Boy Scouts of America expelled James

4. See Diane Freda, Internal Revenue Service Ends 2004 Audit of NAACP, Finding No Political Intervention, DaILy TAX ReP., Sept. 1, 2006, at G-5; Diane Freda, IRS Finds Prohibited Political Activity in Nearly Three-Fourths of EO Exams, DaILY TAX REP., Feb. 27, 2006, at GG-1; Diane Freda, Church Status in Question as IRS Looks into Guest Pastor's Anti-War Comments, DAILY TAX REP., Nov. 8, 2005, at G-6.

5. Panel on the Nonprofit Sector, About the Panel on the Nonprofit Sector, http://www.nonprofitpanel.org/about/ (last visited Mar. 26, 2007).

6. Id.

7. See Panel on the Nonprofit Sector, Strengthening Transparency Governance ACCOUNTABILITY OF Charitable Organizations (2005), http://www.nonprofitpanel.org/final/Panel_Final_Report.pdf. The Panel issued a supplemental report on April 24, 2006 containing recommendations in nine different areas with respect to charitable organizations. Diane Freda, Panel Releases LongA waited Second Report on Needed Industry Reforms, DAILY TAX REP., Apr. 25, 2006, at G-7.

8. Fred Stokeld, State Legislatures Joining Charity Reform Bandwagon, 108 TAX Notes 183, 183; see also Dolores W. Gregory, As States Attempt to Ramp Up Oversight of Public Charities, Some Look to Sarbanes-Oxley as Model for Audit Requirements, Daily Tax Rep., Sept. 13, 2005, at J-1.

9. 530 U.S. $640(2000)$. 
Dale, an assistant scoutmaster, after he publicly declared his homosexuality. ${ }^{10}$ The New Jersey Supreme Court determined that the Boy Scouts' revocation of Dale's membership violated the state's public-accommodations law, which prohibited discrimination on the basis of sexual orientation. ${ }^{11}$ Adopting a divergent view, the United States Supreme Court concluded that the New Jersey law violated the Boy Scouts' First Amendment rights (specifically, the freedom of expressive association) and upheld the organization's right to exclude homosexuals from its membership. ${ }^{12}$ Aside from its foundation in the First Amendment, the Supreme Court's decision raised a fundamental issue that remains unanswered: should a charitable organization continue to enjoy the benefits of tax-exempt status if it engages in discrimination? ? $^{13}$

The type of discrimination present in Boy Scouts only scratches the surface with respect to seemingly widespread discriminatory practices or policies of charitable organizations. Consider the following recent examples:

1. A Mormon-affiliated university terminated the employment of an adjunct professor who questioned the church's stance on same-sex marriage. ${ }^{14}$

2. A Baptist-affiliated university expelled a student who announced that he was gay on his personal website ${ }^{15}$ In a statement released to the local NBC affiliate, the university president stated that "[t]here are places students with predispositions can go such as San Francisco and the left coast or to many of the state schools." 16

10. Id. at 644 .

11. Dale v. Boy Scouts of Am., 734 A.2d 1196, 1230 (N.J. 1999), rev'd 530 U.S. 640.

12. Boy Scouts, 530 U.S. at 659.

13. See J. Christine Harris, Should Boy Scouts' Policy on Gays Preclude TaxExempt Status?, 31 Exempt Org. TAx Rev. 32 (2001).

14. Todd Hollingshead, BYU Fires Teacher Over Op-Ed Stance, Salt LaKE TRIB., June 14, 2006. The article refers to four other "high-profile firings" of Brigham Young University professors from 1993 to 1996 due to controversies involving the doctrine of the Church of Jesus Christ of Latter Day Saints. Id.

15. Mark Pitsch, Student Expelled from University of Cumberlands for Being Gay, COurier-J. (Louisville), Apr. 11, 2006. The university's sexual-conduct policy states that "[a]ny student who engages in or promotes sexual behavior not consistent with Christian principles (including sex outside marriage and homosexuality) may be suspended or asked to withdraw from the University of the Cumberlands." Id. In an official statement, Jim Taylor, the university's president, stated that "[w]e are different by design and are non-apologetic about our Christian beliefs." Id.

16. Robert Marus, Gay Student's Expulsion Spawns Uproar at Kentucky Baptist School, AssoC. BAPTIST PRESS, Apr. 11, 2006, http://www.abpnews.com/ 944.article. 
3. A private Lutheran high school expelled two sixteen-year-old girls suspected of being lesbians. ${ }^{17}$ In a letter sent home to parents, the principal stated that, although officials had not witnessed any physical contact between the girls, their friendship was "uncharacteristic of normal girl relationships and more characteristic of a lesbian one."18 The students sued the school for invasion of privacy and discrimination, demanding readmission, requesting damages, and seeking an injunction against the school's exclusionary policy with respect to gay and lesbian students. ${ }^{19}$

4. A private Christian school expelled a fourteen-year-old student because her parents were lesbians. ${ }^{20} \mathrm{~A}$ statement from the school's superintendent explained that the family failcd to meet its admissions criteria. ${ }^{21}$

5. An independent Catholic school fired a religion teacher after her name appeared among the signers of a statement endorsing abortion rights in a full-page advertiseinent in the local newspaper. ${ }^{22}$ After the Equal Employınent Opportunity Commission dismissed her einployment-discrimination claim, the teacher sued the school, the Catholic diocese, and its bishop in federal district court. Both the district court and the Court of Appeals for the Third Circuit dismissed all of her claims. ${ }^{23}$

6. A Catholic elementary school in Ohio fired one of its teachers because she divorced and remarried without first obtaining an annulment. ${ }^{24}$ Similarly, a Catholic school in Kentucky dismissed a fifthgrade teacher after learning that she had remarried in a Presbyterian service without first obtaining an annulment of her first marriage. ${ }^{25}$

7. A Baptist home for children in Kentucky termmated a female employee after approximately seven months of employment because "her admitted homosexual lifestyle is contrary to [the home's] core

17. Lutheran School Suit Tests Legality of Expelling Gays, SAN DiEgo UNION-TRIB., Dec. 30, http://www.signonsandiego.com/uniontrib/20051230/news_ln30expel.html.

18. Id.

19. Id.

20. Robert Paul Reyes, Christian School Expels Student Because Parents Are Lesbians, AM. CHRON., Sept. 24, 2005, http://www.americanchronicle.com/articles/ viewArticle. asp?articleID $=2562$.

21. See id.

22. John Shiffnan, U.S. Court Hears Case of Teacher Fired Over Stance, PHIL. INQUIRER, Jan. 18, 2006, at B2.

23. See id.; Curay-Cramer v. Ursuline Acad. of Wilmington, Del., Inc., 450 F.3d 130 (3d Cir. 2006).

24. Randall Chase, Teacher Challenges Church Teaching, WaSH. Times, Nov. 15, 2003, http://www.washtinies.com/national/20031114-113845-6019r.htm.

25. See id. 
values." ${ }^{26}$ The home made its dismissal decision after a photograph of the employee and her acknowledged life partner was displayed at the Kentucky State Fair, which informed the home of her lesbian lifestyle. ${ }^{27}$

8. A Christian-affiliated law school's current "Policy on Nondiscrimination" with respect to the employment of faculty and staff reads as follows:

The School of Law does not discriminate on the basis of sexual orientation but does discriminate on the basis of sexual misconduct, including, but not limited to, non-marital sexual misconduct, homosexual conduct, or the encouragement or advocacy of any form of sexual behavior that would undermine the Christian identity or faith mission of the Umiversity. ${ }^{28}$

26. Pedreira v. Ky. Baptist Homes for Children, Inc., 186 F. Supp. 2d 757, 759 (W.D. Ky. 2001). The home issued a public statement addressing the dismissal, stating that "[i]t is important that we stay true to our Christian values. Homosexuality is a lifestyle that would prohibit employment." Id.

27. Id.

28. Liberty Univ. Sch. of Law, Notice of Nondiscrimination, http://www.liberty.edu/academics/law/index.cfm?PID =8533 (last visited Mar. 26, 2007). The language of the school's admissions policy is similar but does not mention homosexual conduct. Id. In the interest of full disclosure, the employment policy further states that

[tlhis policy statement is neither intended to discourage, nor is it in fact applicable to, any analytical discussion of law and policy issues involved in the regulation of sexual behavior, or to discussions of any recommendations for changes in existing law. Discussions of these matters are both practiced and are welcomed within our curriculum.

Id. In comparison, the statement of nondiscrimination of the Columbus School of Law of the Catholic Umiversity of America with respect to admissions is similar:

The university fully accepts the teachings of the Catholic church with regard to homosexual conduct and sexual conduct outside the bounds of matrimony, as set forth by the Magisterium of the Catholic Church. Consistent with those teachings, the university does not discriminate purely on the basis of an individual's sexual orientation without regard to homosexual conduct or other actions that undermme the university's Catholic identity.

Columbus Sch. of Law, Catholic Univ. of Aın., Statement of Nondiscrimination as Accepted by the Association of American Law Schools, http://law.cua.edu/admissions/CSL/nondiscrimination.cfm (last visited Mar. 26, 2007). The nondiscrimination statement of the Villanova University School of Law with respect to admissions states that

[als a Roman Catholic and Augustinian institution, the School of Law strongly affirms the teaching of the Church on the rights and dignity of all persons, and hence condemns discrimination on the basis of a person's 
Because charitable organizations receive direct governmental support or "subsidies" ${ }^{29}$ via tax-exempt status and a charitablecontributions deduction for their donors, the primary question raised by the above instances of alleged, actual, or potential discrimination is whether these organizations should continue to receive such tax benefits if they engage in discrimination. ${ }^{30}$ Currently, federal income-tax law does not explicitly address or proscribe discrimination by charitable organizations. ${ }^{31}$ The only possible restraint on discrimination exists in the public-policy doctrine enunciated by the U.S. Supreme Court in Bob Jones University $v$. United States, which granted the Treasury Department (and the IRS by delegation) the power to revoke the taxexempt status of an organization whose purpose violates "established public policy." ${ }^{2}$

The IRS, however, has used the public-policy doctrine as the basis for revocation only with respect to organizations that participated in racial discrimination, advocated civil disobedience, or involved themselves in an illegal activity. ${ }^{33}$ Although arguably well-intentioned, the doctrine presents more questions than it answers-the most important of which is what constitutes "established public policy." Furthermore, other questions pertaining to the doctrine remain unanswered and may be unanswerable, including (1) whether discrimination on the basis of sexual orientation violates an established public policy, and (2) if an established public policy changes and denies protection to a previously protected segment of the population, whether charitable organizations are then free to discriminate against the

sexual orientation. This position is consistent with the Church's teaching on human sexuality, which does not endorse homosexual conduct. The School of Law accordingly reaffirms its commitment to providing an inclusive and supportive community for all, regardless of sexual orientation.

Villanova Univ. Sch. of. Law, Admissions: Non-Discrimination, http://www.law.villanova.edu/admissions/nondiscrimination/ (last visited Mar. 26, 2007).

29. For further discussion on the equivalence of tax exemption and the charitable-contributions deduction to direct government grants of money, see infra notes 208-215 and accompanying text.

30. See David A. Brennen, Tax Expenditures, Social Justice and Civil Rights: Expanding the Scope of Civil Rights Laws to Apply to Tax-Exempt Charities, 2001 BYU L. REv. 167, 169 (2001) [hereinafter Brennen, Tax Expendituresl; see also David A. Brennen, The Power of the Treasury: Racial Discrimination, Public Policy and "Charity" in Contemporary Society, 33 U.C. Davis L. Rev. 389, 391 (2000) [hereinafter Brennen, Racial Discrimination].

31. Brennen, Tax Expenditures, supra note 30, at 169.

32. See 461 U.S. 574,586 (1983).

33. Brennen, Racial Discrimination, supra note 30 , at 391 n.2 (citing Rev. Rul. 75-384, 1975-2 C.B. 204; Rev. Rul. 71-447, 1971-2 C.B. 230; I.R.S. Gen. Couns. Mem. 39,862 (Dec. 2, 1991)). 
members of that segment. In addition to these questions, critics routinely note that the public-policy doctrine places too much discretion with a regulatory agency. ${ }^{34}$

This Article attempts to fill the void in current fedcral income-tax law with respect to the discriminatory practices of charitable organizations by proposing the enactment of a broad and well-defined nondiscrimination requirement in section $501(\mathrm{c})(3) .^{35}$ Inherent in this proposal is the notion that discrimmation by a charitable organization, including employment and the provision of services, is intrinsically incompatible with the organization's charitable purpose and mission. This nondiscrimination provision should be based on existing language in current civil-rights laws, but should be expanded to reflect the bases on which charitable organizations most commonly discriminate-sexual orientation and marital status. This Article's proposal, however, excepts churches from the nondiscrimination requirement because courts would likely view an imposition of such a requirement as regulating religious belief in violation of the First Amendment's free exercise clause. This exception defines "church" narrowly with an emphasis on a regular congregation and does not include common church-affiliated entities such as schools, universities, and socialservice agencies. ${ }^{36}$

Part II of this Article provides a statutory and regulatory framework for the proposal, including an analysis of the meaning of "charitable" under section 501(c)(3). It scrutinizes the failure of the existing framework and the public-policy doctrine to resolve the problem of discrimination by charitable organizations. Part III critiques noteworthy proposals: The first focuses on an expanded scope of the public-policy doctrine. The second expands the applicability of current civil-rights law to charitable organizations. Both of these, however, fail to effectively combat discrimination by charitable organizations on the bases of sexual orientation and marital status. Finally, Part IV offers an alternative approach to the problem of discrimination in the charitable sector that does not rely on other existing laws, which are of questionable application and lack the necessary breadth. The adoption of a nondiscrimination requirement would transform section 50I(c)(3) into the "gold standard" for all tax-exempt organizations, ensuring that

34. Brennen, Tax Expenditures, supra note 30, at 186-87; Brennen, Racial Discrimination, supra note 30, at 411-28, 446; Charles O. Galvin \& Neal Devins, $A$ Tax Policy Analysis of Bob Jones University v. United States, 36 VAND. L. REv. $1353,1372-73$ (1983).

35. I.R.C. \& 501(c)(3) (2000).

36. See infra notes 326-28 and accompanying text. 
their beneficiaries are as diverse and all encompassing as the taxpaying public from which such organizations draw their support. ${ }^{37}$

\section{The Evolving Meaning of "Charitable"}

\section{A. What Is "Discrimination"?}

Any attempt to define "discrimination" can cause consternation and incite controversy. A legal dictionary defines it, in part, as "a failure to treat all persons equally when no reasonable distinction can be found between those favored and those not favored." ${ }^{38}$ It further provides that

[t]he dictionary sense of "discrimination" is neutral while the current political use of the term is frequently non-neutral, pejorative. . . . For some, it may be enough that a practice is called discriminatory for them to judge it wrong. Others may be mystified that the first group condemns the practice without further argument or inquiry. Many may be led to the false sense that they have actually made a moral argument by showing that the practice discriminates (distinguishes in favor of or against). The temptation is to move from " $X$ distinguishes in favor of or against" to " $X$ discriminates" to " $X$ is wrong" without being aware of the equivocation involved. ${ }^{39}$

This Article relies predominantly on the unequal treatment aspect of the definition, which clearly applies to the above illustrations of discriminatory practices of charitable organizations because those organizations imposed unequal or differential treatment in the context of hiring or firing employees, or in providing the services or activities for which they were granted tax-exempt status. Acknowledging the slippery slope that the use of the term engenders, it is important to

37. Tax-exempt organizations draw their support "directly" from the general public by means of charitable contributions from donors, who receive a corresponding deduction. See I.R.C. $\S 170$ (a)(1) (2000); infra notes 41-42 and accompanying text. Such organizations also receive support "indirectly" from the general public in the form of their tax-exempt status, which arguably constitutes a government subsidy or appropriation. See infra notes 209-19 and accompanying text.

38. BLACK'S LAW DictionaRY 500 (8th ed. 2004).

39. Id. at 500 (citing Robert K. FUllinwider, THE REVERSE Discrimination CONTROVERSY: A MORAL AND LEGAL ANALYSIS 11-12 (1980)). 
consider the bases for federal income-tax exemption and whether discrimination comports with those bases.

\section{B. The Federal Income-Tax Exemption}

In order to discuss the incongruity of deeming a discriminatory organization "charitable," it is neeessary to understand the exemption statute and the regulatory tests that must be satisfied before the IRS grants an exemption. Section 501(c)(3) provides a federal income-tax exemption for nonprofit corporations and certain other entities "organized and operated exclusively for religious, charitable, scientific, ... . or educational purposes, . . . no part of the net earnings of which inures to the benefit of any private shareholder or individual." 40 The principal benefit of a section 501(c)(3) exemption is that the exempt organization is entitled to receive charitable eontributions that are taxdeductible to its donors under section $170(a)(1) .^{41}$ For the most part, only organizations exempt under section 501(c)(3) are eligible for this valuable benefit. ${ }^{42}$

IRS regulations and rulings define each of the eight specific exempt purposes listed in the statute (for exanıle, religious, charitable, and educational). ${ }^{43}$ Section 501(c)(3) establishes both an organizational test and an operational test for determining whether an organization fulfills its exempt purposes; $;^{44}$ to qualify for exemption, an organization must meet both tests. ${ }^{45}$ The organizational test relates solely to the language used in the organization's governing docunients. ${ }^{46}$ An

40. I.R.C. § 501(c)(3) (2000). Specifically, section 501(a) provides that "[a]n organization described in subsection (c) or (d) . . . shall be exempt from taxation under this subtitle." Id. §501(a).

41. Id. $\S 170(\mathrm{a})(1)$ ("[T]here shall be allowed as a deduction any charitable contribution ... payment of which is made within the taxable year."). Donors must primarily make contributions to either governmental entities or charitable organizations under section 501(c)(3). See id. §170(c)(1)-(2).

42. Certain veterans organizations, fraternal organizations, and cemetery organizations, which are exempt from federal incoine tax under other subsections of section 501(c), are also entitled to receive tax-deductible contributions. See id. $\S$ 170(c)(3)-(5).

43. The eight exempt purpoess are as follows: religious, charitable, scientific, testing for public safety, literary, educational, or prevention of cruelty to children or animals, or fostering amateur sports competitions. See I.R.C. § 501(c)(3); see also Treas. Reg. $\S 1.501$ (c)(3) (as ammended in 1990). The IRS has determined that other qualifying purposes meet the overall public-benefit principle of section 501(c)(3) based on an expansive interpretation of "charitable." See Brennen, Tax Expenditures, supra note 30 , at 178 .

44. I.R.C. \& 501(c)(3) (2000).

45. Treas. Reg. $\S 1.501(\mathrm{c})(3)-1(\mathrm{a})(1)$ (as amended in 1990).

46. See id. §1.501(c)(3)-1(b)(1)(i). 
organization meets the requirements of the test if it was organized exclusively for at least one tax-exempt, charitable purpose. ${ }^{47}$ This is possible only if the organizing document (1) limits the organization's purpose to one or more exempt purposes, and (2) does not expressly empower it to substantially engage in activities that do not further any exempt purposes. ${ }^{48}$ The organizational test also imposes requirements on the distribution of the organization's assets upon dissolution. ${ }^{49}$

The purpose of the operational test is to ensure that an exempt organization's resources and activities are devoted primarily to its exempt purposes. The regulations break down the operational test into two components: (1) the primary-purpose-or-activity test and (2) the private-inurement prohibition. ${ }^{50}$ Under the primary-purpose-or-activity test, "an organization will be regarded as operated exclusively for one or more exempt purposes only if it engages primarily in activities which accomplish one or more of such exempt purposes specified in section 501(c)(3)." ${ }^{51}$ An organization will not pass this test if "more than an insubstantial part of its activities is not in furtherance of an exempt purpose." ${ }^{22}$

Under the private-inurement prohibition, an organization will not satisfy the operational test "if its net earnings inure in whole or in part to the benefit of private shareholders or individuals." ${ }^{33}$ The regulations define the term "private shareholder or individual" as "persons having a personal and private interest in the activities of the organization," 54 such as officers, directors, or other individuals in a position to assert influence or control over the organization's operations and activities. ${ }^{55}$ The prohibition is absolute-any amount of inurement is impermissible. ${ }^{56}$ Organizations exempt under section 501(c)(3) are also

47. $\quad$ See id. $\S 1.501(\mathrm{c})(3)-1(\mathrm{a})(1)$.

48. Id. $\S 1.501(\mathrm{c})(3)-1(\mathrm{~b})(1)(\mathrm{i})$

49. See id. $\S 1.501$ (c)(3)-1(b)(4). The IRS typically implements this regulation by requiring an organization, either in its governing document or under relevant state law, to explicitly dedicate its assets to one or more exempt purposes in the event of dissolution. Id.

50. See id. $\S 1.501(\mathrm{c})(3)-1(\mathrm{c})(1)$ to (2).

51. Id. $\S 1.501(\mathrm{c})(3)-1(\mathrm{c})(1)$.

52. Id.

53. Id. $\$ 1.501(\mathrm{c})(3)-1(\mathrm{c})(2)$.

54. Id. $\$ 1.501(\mathrm{a})-1$ (c); see also I.R.S. Gen. Couns. Mem. 39,862 (Dec. 2, 1991) ("The proscription against inurement generally applies to . . . persons who, because of their particular relationship with an organization, have an opportunity to control or influence its activities.").

55. See Bruce R. Hopkins, The Law of Tax-Exempt Organizations $\S 19.3$, at 488 (8th ed. 2003).

56. See Treas. Reg. § 1.501(c)(3)-1(c)(2). 
subject to other statutory and regulatory standards with respect to their operations, including the private-benefit doctrine. ${ }^{57}$

The Supreme Court's Bob Jones University decision imposes the additional, nonstatutory public-policy doctrine on an organization seeking tax-exempt status. ${ }^{58}$ By failing to articulate a clear definition of what constitutes "established public policy," courts have left the doctrine open to the IRS's unfettered discretion, ${ }^{59}$ potentially allowing discrimination to flourish in areas other than race.

\section{The Statutory Impact of "Charitable"}

The failure of the public-policy doctrine to adequately check discrimination and the recent focus on the transparency and accountability of charitable organizations has revived the age-old conundrum of what the expected role of such organizations is in our society. If accountability necessarily implies that organizations must accomplish the purposes for which the government granted them taxexempt status, what is meant by the use of the term "charitable"? More importantly, does our notion of "charitable" apply to all purposes enumerated in section 501(c)(3), so that if one concludes that the antithesis of "charitable" is discrimination, the result is a nondiscrimination requirement applicable to all organizations described under section 501(c)(3)?

Organizations that receive an exemption from federal income tax under section 501(c)(3) are commonly referred to as charitable organizations. ${ }^{60}$ The term "charitable" is used as a collective term, despite the fact that it is one of many descriptive terms used in the statute.$^{61}$ This collective use may be attributed to the fact that all of the organizations described in section 501(c)(3) are eligible to receive taxdeductible charitable contributions. ${ }^{62}$ The term "charitable" originates from the English common law of charitable trusts-specifically, from the defimition of "charitable purposes" in the Preamble to the Statute of Charitable Uses of $1601 .{ }^{63}$ Common-law "charitable" trusts

57. See id. §1.501(c)(3)-1(d)(1)(ii). For further discussion on the privatebenefit doctrine and other operational restrictions, see Nicholas A. Mirkay, Relinquish Control! Why the IRS Should Change Its Stance on Exempt Organizations in Ancillary Joint Ventures, 6 NEV. L. REv. 21, 30-34 (2005).

58. Bob Jones University v. United States, 461 U.S. 574, 585 (1983).

59. See Brennen, Tax Expenditures, supra note 30, at 178 n. 48 .

60. HoPKINS, supra note 55, at 103.

61. See id.

62. See I.R.C. \& 170(c)(2) (2000).

63. HopkINS, supra note $55, \S 5.1$, at 104 . A review of the Statute of Charitable Uses reveals how the term became an expansive concept in that twenty-one 
encompassed "trusts for the relief of poverty; trusts for the advancement of education, trusts for the advancement of religion; and trust for other purposes beneficial to the community, not falling under any of the preceding heads." 64

The most important and relevant concept taken from English law is an "expansive view" of what constitutes "charitable." 65 Legal scholars and courts have concluded similarly "that it is not only impossible, but a mistake to attempt to formulate a clear defmition of charity because 'charitable activity constantly changes' and the question of what is charitable arises in a "number of different contexts." "66 The text of the Restatement (Second) of Trusts-which is explicitly modeled after the Statute of Charitable Uses ${ }^{67}$-and its comments clearly reflect the constantly changing contextual nature of the terms. The comments explain that most charitable purposes "are designed to accomplish objects which are beneficial to the community," 68 and no established benchmark exists "to determine what purposes are of such social

separate charitable activities are enumerated therein. Charles A. Borek, Decoupling Tax Exemption for Charitable Organizations, 31 WM. MrTChell L. REv. 183, 193 (2004). "The activities enumerated include not only relief of aged, impotent, and poor people, but also maintenance of schools of learning and houses of correction, the repair of bridges and churches, and the 'marriage of poor maids." Id.; see also RochELLE Korman, Charitable Class and Need: Whom Should Charities Benefit? 3-4 (2002), http://www.law.nyu.edu/ncpl/library/publications/Korman2002.pdf (" $[\mathrm{P}]$ rcamble to the English Statute of Charitable Uses of 1601 in effect codified the scope of charity that had existed in practice for more than 200 years . . .").

64. HOPKINS, supra note $55, \S 5.1$, at 104.

65. Borek, supra note 63, at 195.

66. Korman, supra note 63, at 6-7 (quoting John P. Persons et al., Criteria for Exemption under Section S01(c)(3), in 4 RESEARCH PAPERS 1909, 1934-35 (1977)). In 1867, Justice Horace Gray of the Massachusetts Supreme Court, in defining charity, enunciated the standard for a "charitable class":

A charity, in the legal sense, may be more fully defined as a gift, to be applied consistently with existing laws, for the benefit of an indefinite number of persons, either by bringing their minds or hearts under the influence of education or religion, by relicving their bodies from disease, suffermg or constraint, by assisting them to establish themselves in life, or by erectimg or maintaining public buildings or works or otherwise lessening the burdens of government.

Jackson v. Phillips, 96 Mass. (14 Allen) 539, 556 (1867).

67. Borek, supra note 63 , at 198 . The Restatement provides as follows: "Charitable purposes include: (a) the relief of poverty; (b) the advancement of education; (c) the advancement of religion; (d) the promotion of health; (e) governmental or municipal purposes; (f) other purposes the accomplishment of which is benefit to the community." RESTATEMENT (SECOND) OF TRUSTS $§ 368$ (1959).

68. Borek, supra note 63, at 198 (quoting RESTATEMENT (SECOND) OF TRUSTS $\S 368 \mathrm{cmt}$. a). 
interest to the community; the interests of the community vary with time and place." ${ }^{69}$

In enacting section 501(c)(3), Congress did not clearly articulate whether the common-law definition of "charitable," or the more "popular and ordinary" usage of the term-namely, relief of the poor ${ }^{70}$-guided it. ${ }^{71}$ Although this distinction is arguably a semantic difference, it affects two important implications: (1) "the meaning to be ascribed to the term charitable as used in . . . [section] 501(c)(3)," and (2) "whether the entirety of that section is intended to describe organizations that are in some sense charitable." 72 Under canons of statutory construction, the disjimctive enumeration of purposes in section 501(c)(3) leads to the conclusion that Congress intended to grant tax-exempt status to any organization organized and operated for one of these enumerated purposes. ${ }^{73}$ Accordingly, one conclusion is that the section 501(c)(3) purposes "are not overlain with a requirement that all organizations, to be exempt under that section, must qualify as entities that are charitable in the common law sense." 74

Legislative history-in the form of a 1939 report of the House of Representatives-however, appears to illustrate otherwise: $:^{75}$

The exemption from taxation of money or property devoted to charitable and other purposes is based upon the theory that the Government is compensated for the loss of revenue by its relief from financial burdens which would otherwise have to

69. Id. (quoting RESTATEMENT (SECOND) OF TRUSTS $\S 368 \mathrm{cmt} . \mathrm{b}$ ).

70. HoPKINS, supra note 55, § 5.1, at 104.

71. Id. $\S 5.2$, at 106.

72. Id. (emphasis omitted).

73. Id. (quoting Reiter v. Sonotone Corp., 442 U.S. 330, 339 (1979) ("Canons of construction ordinarily suggest that terms connected by a disjunctive be given separate meanings, unless the context dictates otherwise.")). Bruce Hopkins further explained that a competing canon of statutory construction provides that "related statutory provisions should be interpreted together," id. (citing Kokoszka v. Belford, 417 U.S. 642 (1974); United States v. Cooper Corp., 312 U.S. 600 (1941)), which he states is particularly relevant because section $170(c)(2)$ 's charitable contribution deduction "reiterate[sl the separate and disjunctive purposes or functions described in [section] 501(c)(3)." Id.

74. HOPKINS, supra note $55, \S 5.2$, at 107 (emphasis omitted). Hopkins also argued that this conclusion conforms with another canon of statutory construction"statutes are to be construed to give effect to each word and that no one part of a statute should be interpreted so as to render another part of the statute redundant." Id. § 5.2 , at 107 n.26 (citing Jarecki v. G.D. Searle \& Co., 367 U.S. 303 (1961); United States v. Menasche, 348 U.S. 528 (1955)).

75. HoPKINS, supra note $55, \S 5.2$, at 108 . 
be met by appropriations from other public funds, and by the benefits resulting from the promotion of general welfare. ${ }^{76}$

The use of the terms "public" and "general welfare" in the report appears to establish an obligation to follow the common-law meaning of "charitable." Earlier legislative history lends further support to a broader interpretation of the term. ${ }^{78}$

The IRS promulgated the current regulations interpreting "charitable" in section 501(c)(3) in 1959, broadening the meaning of the term immensely. ${ }^{79}$ The regulations unmistakably acknowledge that an organization may qualify under a section 501(c)(3) purpose, regardless of whether the purpose comports with the common-law definition of "charitable" 80 .

The term "charitable" is used in section 501(c)(3) in its generally accepted legal sense and is, therefore, not to be construed as limited by the separate enumeration in section 501(c)(3) of other tax-exempt purposes which may fall within the broad outlines of "charity" as developed by judicial decisions. Such term includes: Relief of the poor and distressed or of the underprivileged; advancement of religion; advancement of education or science; erection or maintenance of public buildings, monuments, or works; lessening of the burdens of Government; and promotion of social welfare by organizations designed to accomplish any of the above purposes, or (i) to lessen neighborhood tensions; (ii) to eliminate prejudice and discrimination; (iii) to defend human and civil rights secured by law; or (iv) to combat community deterioration and juvenile delinquency. ${ }^{81}$

These regulations integrated "the concept that the meaning of charity [is] not static, but was meant to evolve over time to reflect

76. Id. (citing H.R. REP. No. 75-1860, at 19 (1938)).

77. Id. Hopkins additionally stated that, to the contrary, the language "charitable and other purposes" may imply "intent to invoke a narrower meaning of the term charitable." Id.; see also Brennen, Tax Expenditures, supra note 30, at 188 n.90.

78. Id. (explaining that the sponsor of the 1909 tax-exemption statute, which only applied to corporations, stated that Congress drafted the provision to relieve those organizations "devoted exclusively to the relief of the suffering, to the alleviation of our people, and to all things which commend themselves to every charitable and just impulse" from income-tax liability (quoting 44 Cong. Rec. 4150 (1909))).

79. Id. $\S 5.2$, at 110 .

80. Id.

81. Treas. Reg. § 1.501(c)(3)-1(d)(2) (as amended in 1990). 
changing circumstances and the changing views of public benefit." 82 Undeniably, the IRS has liberally and expansively interpreted the ineaning of charitable to address the ever-changing needs of the general public. $^{83}$

Notwithstanding this legislative history, courts have not readily agreed with the regulations' interpretation of section 501(c)(3) ${ }^{84}$ One federal court of appeals concluded that the "term 'charitable' is a generic term and includes literary, religious, scientific and educational institutions." 85 Still another appellate court announced in multiple decisions that charitable-trust rules should be applied in determining the meaning of "charitable," 86 and that it was Congress's intent to apply such rules to "those organizations commonly designated charitable in the law of trusts. " ${ }^{87}$ In Bob Jones University, the Supreme Court noted that Congress only granted the benefit of deductible "charitable contributions" under section 170(a) to certain eligible organizations, which are "virtually identical" to those enumerated in section 501(c)(3) ${ }^{88}$ Accordingly, the Court concluded that Congress intended to provide tax benefits to organizations serving "charitable" purposes, regardless of an organization's specific section 501(c)(3) activities ${ }^{89}$ In other words, each of the eight purposes in section 501(c)(3) falls within a broad classification of "charitable." "In announcing the public-policy doctrine, the Bob Jones University Court solidified the broad view that all tax-exempt organizations described in section 501(c)(3) are considered "charitable."

82. Marion R. FREMONT-SMITH, Governing NonPRofit ORganizations: Federal AND STATE LAW AND REgULATION 101 (2004).

83. Id. at 245.

84. See HopkINS, supra note $55, \S 5.2$, at 110.

85. Id. $\$ 5.2$, at 111 (quoting United States v. Proprietors of Soc. Law Library, 102 F.2d 481, 483 (1st Cir. 1939)).

86. Id. (citing $\mathrm{Pa}$. Co. for Ins. on Lives \& Granting of Annuities v. Helvering, 66 F.2d 284 (D.C. Cir. 1933)).

87. Id. (quoting Int'1 Reforın Fed'n v. Dist. Uneınployment Bd., 131 F.2d 337, 339 (D.C. Cir. 1942)).

88. See Bob Jones Univ. v. United States, 461 U.S. 574, 586-88 (1983). In reaching this conclusion, the Suprene Court adopted the Fourth Circuit's analysis. See Bob Jones Univ. v. United States, 639 F.2d 147, 151 (4th Cir. 1980).

89. See Bob Jones Univ., 461 U.S. at 587-88.

90. HoPKINS, supra note 55, § 5.2, at 107 n.22, 111. 


\section{The Public-Policy Doctrine's Impact on "Charitable"}

\section{BOB JONES UNIVERSITY V. UNITED STATES}

The controversy that culminated in Bob Jones University bcgan in 1970 when a federal district court issued a preliminary injunction compelling the IRS to deny tax exemption to Mississippi private schools with racially discriminatory admissions policies. ${ }^{91}$ Until that time, the IRS granted tax-exempt status to private schools regardless of the existence of these policies. ${ }^{92}$ In response to the injunction, the IRS discontinued granting exemptions and prohibited deductions of charitable contributions to schools that racially discriminatcd. ${ }^{93}$ The IRS notified private schools of this new policy by means of a press release and a letter. ${ }^{94}$ In addition, it issued a revenue ruling that formally established this new policy and required these schools to adopt and maintain a policy of nondiscrimination with respect to students $\mathrm{m}$ the admissions process, scholarship and loan programs, and schooladministered programs (like athletics). ${ }^{95}$

91. See Green v. Kennedy, 309 F. Supp. 1127, 1140 (D.D.C. 1970); see Galvin \& Devins, supra note 34, at 1357 ("The Green [v. Kennedy] court suggested that the IRS would not be permitted to grant tax-exempt status to institutions that violate the government's public policy of nondiscrimination."). In Green v. Connally, the district court permanently enjoined the IRS from granting tax-exempt status to any Mississippi school that failed to publicly sustain a nondiscrimination policy. $330 \mathrm{~F}$. Supp. 1150 (D.D.C.), aff'd sub nom. Coit v. Green, 404 U.S. 997 (1971)

92. Bob Jones Univ., 461 U.S. at 577.

93. See Press Release, 1.R.S., 1.R.S. Announces Position on Private Schools (July 10, 1970), reprinted in Tax-Exempt Status of Private Schools: Hearings Before the Subcomm. on Oversight of the H. Comm. on Ways and Means, 96th Cong. 10 (1979); see also Brennen, Racial Discrimination, supra note 30, at 400-01.

94. II.; Bob Jones Univ., 461 U.S. at 578.

95. See Rev. Rul. 71-447, 1971-2 C.B. 230. In explaining the basis for the ruling, the IRS stated the following:

Under common law, the term "charity" encompasses all three of the major categories identified separately under section 501(c)(3) of the Code as religious, educational, and charitable. Both the courts and the Internal Revenue Service have long recognized that the statutory requirement of being "organized and operated exclusively for religious, charitable, $* * *$ or educational purposes" was intended to express the basic common law concept. Thus, a school asserting a right to the benefits provided for in section 501(c)(3) of the Code as being organized and operated exclusively for educational purposes must be a common law charity in order to be exempt under that section.

Id. In concluding that a school without a racially nondiscriminatory policy with respect to students is not "charitable," the IRS relied on the charitable-trust principle that "the purpose of the trust may not be illegal or contrary to public policy." Id. The IRS 
Bob Jones University's mission was "to conduct an institution of learning . . . giving special emphasis to the Christian religion and the ethics revealed in the Holy Scriptures." that the Bible forbids interracial dating and marriage, the Greenville, South Carolina institution sustained a racially discriminatory admissions policy. ${ }^{97}$ Upon formal notification by the IRS of the new nondiscrimination requirement for private schools, Bob Jones University first filed suit in 1971 in an attempt to protect its tax-exempt status. ${ }^{98}$ On January 19, 1976, the 1RS revoked the university's charitable exemption retroactive to the day after the date on which the university received the notification letter regarding the IRS's change in policy for private schools. ${ }^{99}$

As a vehicle for challenging the revocation of its exemption, the university challenged the revocation of its exemption by filing a second suit in federal district court seeking a refund of federal unemployment

subsequently released guidelines for determining whether private schools had adequately publicized their racially nondiscriminatory policy. See Rev. Proc. 72-54, 1972-2 C.B. 834; Rev. Proc. 75-50, 1975-2 C.B. 587. The guidelines require scbools to (1) declare their racially nondiscriminatory policy in their governing documents and catalogs, (2) make their policy known to all segments of the community through newspapers and broadcast media, and (3) keep detailed records demonstrating their compliance with such guidelines. See id. at 587-88, 590. Furthermore, the IRS announced its demial of tax-exempt status to any religious organization with racially discriminatory policies, even if sincere religious belief served as the foundation for the discrimination. See Galvin \& Devins, supra note 34, at 1358 n.23 (citing Rev. Rul. 75231, 1975-1 C.B. 158).

96. Bob Jones Univ., 461 U.S. at 579-80. Although not affiliated with any particular Christian denomination, the university is "dedicated to the teaching and propagation of its fundamentalist Christian religious beliefs." Id. at 580 .

97. See id. at 580. Specifically, the university admitted no black students until 1971. Id. From 1971 to 1975 , it continued its discrimination agamst unmarried blacks, but accepted applications from black students married within their race. Id. In accordance with the Fourth Circuit's decision in McCrary v. Runyon, 515 F.2d 1082 (4th Cir. 1975), aff'd 427 U.S. 160 (1976), which determined that racial exclusion from private schools was illegal, the university admitted unmarried blacks. See Bob Jones Univ., 461 U.S. at 580. It maintained a disciplinary rule that prohibited interracial dating and marriage, however, and denied admissions to prospective students and expelled enrolled students that violated the rule. See $i d$. at 580-81.

98. Bob Jones University's first suit culminated in Bob Jones University $v$. Simon, 416 U.S. 725 (1974). There, the Supreme Court held that the Tax AntiInjunction Act, I.R.C. $\S 7421$ (a) (2000), did not permit the university to obtain judicial review through an injunctive action prior to the assessment or collection of any tax. Bob Jones Univ., 461 U.S. at 581 (discussing Bob Jones Univ., 416 U.S. 725).

99. Bob Jones Univ., 461 U.S. at 581. The university received a letter from the IRS dated November 30,1970 . Id. In addition to stating the IRS's new policy, the letter also announced the agency's "intention to challenge the tax-exempt status of private schools practicing racial discrimination in their admissions policies." Id. 
tax paid to the IRS. ${ }^{100}$ The government counterclaimed for unpaid taxes. ${ }^{101}$ The district court determined that the revocation of the university's exempt status exceeded the IRS's delegated powers and violated the university's First Amendment religious rights. ${ }^{102}$ The Fourth Circuit Court of Appeals reversed the district-court decision on appeal, stating that an educational institution must be "charitable' in the common law sense, and . . . must not be contrary to public policy" to be eligible for exemption. ${ }^{103}$ Furthermore, the court of appeals determined that the university failed this requirement, because its "racial policies violated the clearly defined public policy, rooted in our Constitution, condemning racial discrimination and, more specifically, the government policy against subsidizing racial discrimination in education, public or private." 104

The Supreme Court affirmed the Fourth Circuit's decision by a vote of eight to one. ${ }^{105}$ The Court noted that, in order to qualify for exempt status under section 501(c)(3), an organization must (1) fall within one of the eight categories set forth in the statute, and (2) demonstrate that its activities are not contrary to established public policy ${ }^{106}$ In opting for a broader concept of charity, the Court rejected the university's argument that the eight categories in the statute are disjunctive and, therefore, an organization need not also qualify as "charitable" to be tax-exempt. ${ }^{107}$ The Court observed that, although section 501(c)(3) does not explicitly impose a public-policy limitation, Congress nevertheless intended that "entitlement to tax exemption depends on meeting certain common-law standards of charity-namely, that an institution ... must serve a public purpose and not be contrary to established public policy." 108

The Court further observed the interaction between sections 170 and 501(c)(3):

100. Id. at 581-82.

101. Id. at 582 .

102. Id.

103. Id.; see also Bob Jones Univ. v. United States, 639 F.2d 147, 151 (4th Cir. 1980).

104. Bob Jones Univ., 461 U.S. at 582 (quoting Bob Jones Univ., 639 F.2d at $151)$.

105. Id. at 585 .

106. Id.

107. See id. at 585-86.

108. Id. at 586. In response to the university's "plain language" argument that section 501(c)(3) was devoid of any "charitable" overlay to all of the purposes delineated therein, the Court stated that "[i]t is a well-established canon of statutory construction that a court should go beyond the literal language of a statute if reliance on that language would defeat the plain purpose of the statute." Id. 
[Section] 170 reveals that Congress'[s] intention was to provide tax benefits to organizations serving charitable purposes. The form of [section] 170 simply makes plain what common sense and history tell us: in enacting both [section] 170 and [section] 501(c)(3), Congress sought to provide tax benefits to charitable organizations, to encourage development of private institutions that serve a useful public purpose or supplement or take the place of public institutions of the same kind. ${ }^{109}$

Accordingly, the Bob Jones University decision solidified the view that there is a "charitable" overlay to all exempt organizations described in section 501(c)(3), and thereby provided the means necessary to impose a public-policy limitation. ${ }^{110}$

To support its conclusion that Bob Jones University violated an "established public policy" and, thus, could not be considered charitable, the Supreme Court stated that "[a]n unbroken line of cases following Brown v. Board of Education establishes beyond doubt this Court's view that racial discrimination in education violates a most fundamental national public policy, as well as rights of individuals." ${ }^{111}$ In addition to Brown, the Court relied on the civil-rights acts, as well as executive orders issued over a forty-year period, to conclude that eliminating racial discrimmation was an established national public policy. ${ }^{112}$ Ultimately, the Court relied on the aggregated

109. Id. at 587-88 (footnote omitted). In enunciating a fairly broad standard for tax exemption, the Court explained that the the public benefit derived from the organization's activities justifies its exemption. Id. at 591. Furthermore, an organization's purpose must fall within one of the eight categories set forth in section $501(c)(3)$ and "must demonstrably serve and be in harmony with the public interest." Id. at 592. The Court cautioned, however, that the organization's purpose "must not be so at odds with common community conscience as to undermine any public benefit that might otherwise be conferred." Id.

110. Cf. Miriam Galston, Public Policy Constraints On Charitable Organizations, 3 VA. TAX REv. 291, 292 (1984). As the lone dissenter in Bob Jones University, Justice William Rehnquist rejected the notion that there existed a charitable overlay to each of the delineated purposes in section 501(c)(3). He concluded that "the legislative history of [sectionl 501(c)(3) unmistakably makes clear that Congress has decided what organizations are serving a public purpose and providing a public benefit within the meaning of [section] 501(c)(3) and has clearly set forth in [sectionl 501(c)(3) the characteristics of such organizations." Bob Jones Univ., 461 U.S. at 615 (Rehnquist, J., dissenting); see also Galvin \& Devins, supra note 34, at 1363.

111. Bob Jones Univ., 461 U.S. at 593 (citing Brown v. Bd. of Educ., 347 U.S. 483 (1954)).

112. See id. at 593-95; Brennen, Racial Discrimination, supra note 30, at 40304. 
pronouncements of all three branches of government as constituting established public policy.

The Supreme Court rejected the university's argument that the Treasury Department overstepped its lawful bounds in issuing the 1970 and 1971 rulings and notices through the IRS, noting that the Treasury had consistently received "broad authority" from Congress to interpret tax laws. ${ }^{113}$ Furthermore, the Court concluded that the IRS's primary responsibility of determining whether an entity is "charitable" under sections 170 and 501(c)(3) "may necessitate later determinations of whether given activities so violate public policy that the entites involved cannot be deemed to provide a public benefit worthy of 'charitable' status." ${ }^{14}$ Finally, in response to the university's argument that the public-policy doctrine violated its First Amendment free exercise rights, the Court affirmed that certain compelling governmental interests can justify regulating certain religious conduct. ${ }^{115}$ In finding that the government's interest in eradicating racial discrimination in education was sufficiently compelling to overcome any First Amendment concerns, the Court concluded that the "[d]enial of tax benefits will inevitably have a substantial impact on the operation of private religious schools, but will not prevent those schools from observing their religious tenets." 116

\section{CRITIQUE OF THE PUBLIC-POLICY DOCTRINE}

Although it arguably achieves the correct result, Bob Jones University has nevertheless sparked extensive deliberation and criticism. Critics have disparaged the Court for concluding that a charitable overlay to section 501(c)(3) exists and imposing a public-

113. See Bob Jones Univ., 461 U.S. at 596-97.

114. Id. at 597-98; see also Brennen, Racial Discrimination, supra note 30, at 404-05 (discussing legislative events occurring after the IRS's adoption of the publicpolicy limitation in 1970, which made "an unusually strong case of legislative acquiescence . . . and ratification" by Congress (quoting Bob Jones Univ., 461 U.S. at 599)).

115. Bob Jones Umiv., 461 U.S. at 603. The Court relied, in part, on Prince v. Massachusetts, 321 U.S. 158 (1944), which held that "neutrally cast child labor laws prohibiting sale of printed materials on public streets could be applied to prohibit children from dispensing religious literature." Bob Jones Univ., 461 U.S. at 603.

116. Id. at 603-04. The Court further concluded that the government's interest "substantially outweighs whatever burden denial of tax benefits places on petitioners' exercise of their religious beliefs. The interests asserted by [the university] cannot be accommodated with that compelling governmental interest, . . . and no "less restrictive means' . . . are available to achieve the governmental interest." Id. at 604 (citations omitted). 
policy limitation on the statute. ${ }^{117}$ They have likewise rebuked the Court for "abdicat[ing] its supervisory powers to the IRS" and "supplant[ing] the role of Congress as lawmaker by making broad tax policy pronouncements," rather than exercising the oversight necessary to ensure that the IRS properly enforces the tax laws. ${ }^{118}$

Professor David A. Brennen has criticized the doctrine as lacking legal or statutory authority and a "clearly defmed scope of applicability." 119 Since the IRS's adoption of its racial nondiscrimination policy in 1970, Congress has neither enacted any law that codifies the public-policy doctrine ${ }^{120}$ nor provided the IRS with the "legal authority to act solely on public policy grounds." 221 As a consequence, Brennen questioned whether the IRS is the appropriate federal agency to determine if a charitable organization violates an established public policy. ${ }^{122}$ In his Bob Jones University concurrence, Justice Lewis Franklin Powell, Jr., appeared to agree. To support his assertion that this task belongs to Congress, Justice Powell quoted Justice Harry Blackmun's dissent in a prior Supreme Court decision:

[W] here the philanthropic organization is concerned, there appears to be little to circumscribe the almost unfettered power of the Commissioner [of the IRS]. This may be very well so long as one subscribes to the particular brand of social policy the Commissioner happens to be advocating at the time . . . but application of our tax laws should not operate in so fickle a fashion. Surely, social policy in the first instance is a matter for legislative concern. ${ }^{123}$

117. See, e.g., Galvin \& Devins, supra note 34, at 1379-80; Galston, supra note 110 , at 292 .

118. Galvin \& Devins, supra note 34 , at 1379.

119. Brennen, Tax Expenditures, supra note 30, at 186.

120. See id. at $186 \mathrm{n} .83$.

121. Id. at 187; Brennen, Racial Discrimination, supra note 30, at 446; Galvin \& Devins, supra note 34 , at 1379. Congress did, however, enact section 501(i), which prohibits certain discrimination by social clubs. See I.R.C. $\S 501$ (i) (2000). Justice Rehnquist referred to the existence of section 501(i) in his Bob Jones University dissent as evidence that if Congress "wants to add a requirement prohibiting racial discrimination to one of the tax-benefit provisions, it is fully aware of how to do it." Bob Jones Univ., 461 U.S. at 621 (Rehnquist, J., dissenting).

122. See, e.g., Brennen, Racial Discrimination, supra note 30, at 411-28.

123. Bob Jones Univ., 461 U.S. at 611-12 (quoting Comm'r v. "Ams. United" Inc., 416 U.S. 752, $774-75$ (1974) (Blackmun, J., dissenting)); see also Michael Hatfield et al., Bob Jones University: Defining Violations of Fundamental Public Policy, in 6 TOPICS IN PHILANTHROPY 1, 14 (2000), available at http://www.law.nyu.edu/ncpl/library/publications/Monograph2000BobJones.pdf; Galvin \& Devins, supra note 34, at 1373. 
Brennen has argued that this lack of IRS authority forced the $B o b$ Jones University Court to rely on an expansive interpretation of "charitable" in section 501(c)(3) as justification for the IRS's publicpolicy power. ${ }^{124}$ In disagreeing with such a broad reading of "charitable," Brennen concluded that the Court's decision failed to "address the limits of the Treasury's ability to determine when or if a particular 'public policy' is sufficiently 'established' in any context other than whites discriminating against blacks." ${ }^{125}$ Accordingly, Brennen raised the fundamental issue of which sources of law or current policy the IRS should consult to determine that a national public policy exists. ${ }^{126}$ While the Court looked to all three branches of government to conclude that an established public policy existed, ${ }^{127}$ it is unclear whether this standard is too restrictive to be applied in all instances or if a broader view of public policy should be adopted. ${ }^{128}$ The lack of a clearly defined source of public policy is only compounded by the significant evidentiary burden placed on the IRS to determine and prove that an organization's activities violate a fundamental public policy. ${ }^{129}$

124. Brennen, Tax Expenditures, supra note 30, at 186-87.

125. Brennen, Racial Discrimination, supra note 30, at 407; see also supra note 112 and accompanying text.

126. See id. at 436-39. For instance, no federal public policy or law prohibiting discrimination on the basis of sexual orientation currently exists. Hatfield et al., supra note 123 , at 78 . This continues in spite of the fact that numerous municipalities and some statcs have enacted ordinances and laws prohibiting such discrimination. Id. Indeed, Congress's actions to date fail to "come within the standards envisioned by the $B o b$ Jones Court for proving the existence of a fundamental national public policy against sexual orientation discrimination." Id. at 86-87.

127. See Bob Jones Univ., 461 U.S. at 598.

128. See HopkINS, supra note 55, $\$ 5.4$, at 107 ("[I]t may also be quite validly asserted that there is a federal public policy, either presently in existence or in the process of development, against other forms of discrimination, such as discrimmation on the basis of marital status, national origin, religion, handicap, sexual preference, and age."); see also Gay Rights Coal. of Georgetown Univ. Law Ctr. v. Georgetown Univ., 536 A.2d 1, 38-39 (D.C. Ct. App. 1987) (holding that Georgetown University violated a District of Columbia law prohibiting an educational institution from discriminating against an individual on the basis of sexual orientation, and concluding that the "eradication of sexual orientation discrimination is a compelling governmental interest"); cf. Hatfield et al., supra note 123, at 86-87 (concluding that there is no "fundamental national public policy against sexual orientation discrimination").

129. Hatfield et al., supra note 123, at 16. Beyond the evidentiary burden, the "IRS may also be loathe to jeopardize its own independence. Taking action against an organization for violating public policy, the IRS risks being reined in by the Congress or the President. Already unpopular, it may seem foolhardy to IRS officials to take a stand on controversial political issues." Id. The IRS has acknowledged this difficulty in its own training materials on the public-policy doctrine: "Deciding a case on the basis of public policy rather than a specific law is difficult because it requires discerning 
Ultimately, the absence of a clearly defined public policy forces the IRS to balance its unfettered discretion in exercising public-policy power with the heavy burden of proving that an "established" policy exists. This difficult balancing act may explain why the IRS has used the public-policy doctrine as the basis for revocation only in instances involving racial discrimination, civil disobedience, or illegal activity. ${ }^{130}$ Furthermore, the lack of a defined public policy also leaves charitable organizations in the precarious position of monitoring the current political climate to ensure that their activities do not violate a contemporary public policy ${ }^{131}$ Reliance on the public-policy doctrine to combat discrimination on the basis of marital status, sexual orientation, or even religion has been futile because such bases are not "established" public policy. Only Congress's enactment of a welldefined nondiscrimination requirement in section 501(c)(3) will effectively end discrimination by charitable organizations. ${ }^{132}$

\section{E. Boy Scouts of America v. Dale: A Missed Opportunity to Clarify the Public-Policy Doctrine's Scope?}

Brennen propounded that Boy Scouts of America v. Dale 133 "implicates fundamental aspects of true democracy"-the convergence of First Amendment free expression rights with state and social goals to eliminate discrimination via antidiscrimination laws. ${ }^{134}$ Clearly, based on the Supreme Court's decision, the First Amendment right to free expression prevailed. ${ }^{135}$ Although it is difficult to argue that the inherent weaknesses of the public-policy doctrine resulted in the decision, it is certainly plausible to conclude that the decision only further exploited the doctrine's weaknesses, ultimately leading to IRS inaction. Due in

what the public policy involved really is." See JEAN Wright \& JAY H. ROTZ, I.R.S., lllegality and Public Policy Considerations 9 (1993).

130. Brennen, Racial Discrimination, supra note 30 , at $391 \mathrm{n} .2$ (citing Rev. Rul. 75-384, 1975-2 C.B. 204; Rev. Rul. 71-447, 1971-2 C.B. 230; I.R.S. Gen. Couns. Mem. 39,862 (Dec. 2, 1991)).

13I. See Galvin \& Devins, supra note 34, at 1373-74 (“[A]n organization's survival may depend on the views of the particular administration in office.").

132. Although Brennen has proposed the codification of the public-policy doctrine as a solution for the doctrine's lack of legal or statutory authority, the doctrine's lack of defined scope and its difficult application prevent it from being a more effective tool for addressing discrimination by charities. See Brennen, Racial Discrimination, supra note 30 , at 446.

133. 530 U.S. $640(2000)$.

134. David A. Brennen, Charities and the Constitution: Evaluating the Role of Constitutional Principles in Determining the Scope of Tax Law's Public Policy Limitation for Charities, 5 FLA. TAX REv. 779, 840 (2002).

135. Id. 
part to the public-policy doctrine's lack of a "clearly defined scope of applicability," 136 the Boy Scouts of America remains a charitable organization under section 501(c)(3) despite its discriminatory policies with respect to homosexuals. ${ }^{137}$ Although Boy Scouts did not involve federal income-tax law directly, in upholding the organization's ban on homosexuals on the basis of their First Amendment right of expressive association, the decision did resurrect the issue of what constitutes an "established" public policy and whether the Boy Scouts' discriminatory policy should preclude its "charitable" designation under section 501(c)(3). ${ }^{138}$ Therefore, in the world of charitable organizations and tax-exempt law, Boy Scouts is more significant for what it did not address than for what it did.

The case arose when a local council of the Boy Scouts expelled James Dale, an assistant scoutmaster, from its membership after he publicly declared his homosexuality. ${ }^{139}$ Dale filed suit in a New Jersey superior court alleging that the Boy Scouts violated a state law, which prohibited discrimination on the basis of sexual orientation in places of public accommodation. ${ }^{140}$ The court's Chancery Division granted summary judgment in favor of the Boy Scouts, but the Appellate Division reversed. ${ }^{141}$ The New Jersey Supreme Court determined that the Boy Scouts' revocation of Dale's violated the publicaccommodations law. ${ }^{142}$ The court held that the application of the state law did not violate the Boy Scouts' First Amendment right of expressive association, because members could still achieve the organization's purposes with Dale as a member. ${ }^{143}$ The court further concluded that the state had a compelling interest in eradicating "the

136. See supra note 119 and accompanying text.

137. The Boy Scouts of America and its local councils are generally exempt under section 501(c)(3). The IRS publishes a list of the organizations eligible to receive tax-deductible charitable contributions. See I.R.S., PUblication 78, CUmulative LisT OF ORGanizations DESCRIBED IN SECTION 170(C) OF THE INTERNAL REVENUE CODE OF 1986 (2006), bttp://www.irs. ustreas.gov/charities/article $/ 0$, id $=96136,00 . \mathrm{html}$.

138. See Harris, supra note 13 , at 32-33.

139. See Boy Scouts, 530 U.S. at 644. Dale "declared" his homosexuality during an interview with a local newspaper at a conference on gay and lesbian teenagers' health. See id. at 645. The newspaper published the interview along with his photograph and a caption identifying him as a leader in the Rutgers University LesbianGay Alliance. Id.

140. Id. at 645 .

141. See id. at 645-46.

142. Id. at 646; see also Dale v. Boy Scouts of Am., 734 A.2d 1196, 1230 (N.J. 1999) (finding that the Boy Scouts were subject to New Jersey's publicaccommodations law).

143. Boy Scouts, 734 A.2d at 1223. 
destructive consequences of discrimination from our society" ${ }^{144}$ and that its public-accommodations law restrained no more speech than necessary to accomplish its purpose. ${ }^{145}$

Adopting a divergent view, the U.S. Supreme Court found that the New Jersey law did violate the Boy Scouts' right of expressive association, and upheld the organization's right to exclude homosexuals. ${ }^{146}$ The majority began its opinion by referring to Roberts v. U.S. Jaycees, ${ }^{147}$ in which the Court discerned that "implicit in the right to engage in activities protected by the First Amendment [is] a corresponding right to associate with others in pursuit of a wide variety of political, social, economic, educational, religious, and cultural ends." 148 The Boy Scouts Court concluded that this "right is crucial in preventing the majority from imposing its views on groups that would rather express other, perhaps unpopular, ideas." 149 In its "limited" inquiry into the Boy Scouts' viewpoints, the Court found that Dale's presence-which the organization asserted would "promote homosexual conduct as a legitimate form of behavior"-would significantly burden the organization's foundation of encouraging its youth membership to be "morally straight" and "clean." ${ }^{50}$ Thus, the Boy Scouts Court summarily concluded that New Jersey's interests failed to "justify such

144. Id. at 1227 .

145. Id. at 1228 (quoting Roberts v. U.S. Jaycees, 468 U.S. 609, 629 (1984)).

146. See Boy Scouts, 530 U.S. at 659.

147. 468 U.S. 609. In Robcrts, the Supreme Court affirmed the application of a Minnesota antidiscrimination law by holding that the First Amendment right of expressive association did not sanction the Jaycees' exclusion of women. See id. at 623 . The Court stated that any restrictions on the freedom of association "may be justified by regulations adopted to serve compelling state interests, unrelated to the suppression of ideas, that cannot be achieved through means significantly less restrictive of associational freedoms." Id. Furthermore, the Court found that the Minnesota statute did not "impose[] any serious burdens on the male members' freedom of expressive association" and that the government's compelling interest in eradicating gender discrimination outweighed any resulting constraints. See id. at 626 .

148. Boy Scouts, 530 U.S. at 647 (quoting Roberts, 468 U.S. at 622).

149. Id. at 647-48. The Court elaborated that the protection of this right is "especially important in preserving political and cultural diversity and in shielding dissident expression from suppression by the majority." Id. at 648 (quoting Roberts, 468 U.S. at 622 ).

150. Boy Scouts, 530 U.S. at $650-51,656$. The notion that Dale's very presence constituted a message buttressed the Court's opinion. See Andrew Koppelman, Signs of the Times: Dale v. Boy Scouts of America and the Changing Meaning of Nondiscrimination, 23 CaRdozo L. Rev. 1819, 1827-28 (2002) ("[The Court] evidently agrees with the claim in the Scouts' hrief that the exclusion of openly gay people was the only way that the Scouts could avoid taking a public position on the morality of homosexual conduct."). 
a severe intrusion on the Boy Scouts' rights to freedom of expressive association." 151

In a spirited dissent, ${ }^{152}$ Justice John Paul Stevens expressed concern that, under the majority's standard, "the right of free speech effectively becomes a limitless right to exclude for every organization, whether or not it engages in any expressive activities." ${ }^{53}$ Relying on the Court's prior decision in Roberts, Justice Stevens concluded that the New Jersey law did not "impose[] any serious burdens" ${ }^{54}$ on the Boy Scouts' "collective effort on behalf of [its] shared goals," or compel the Boy Scouts to communicate a message that it did not wish to endorse. ${ }^{155}$ Similarly, Justice David Souter contended in his dissent that the

151. Boy Scouts, 530 U.S. at 659. Professor Andrew Koppelman has noted that the Supreme Court failed to discuss what New Jersey's interests were. Koppelman, supra note 150 , at $1835 \mathrm{n} .81$.

152. Justices David Souter, Ruth Bader Ginsberg, and Stephen Breyer joined in Justice Stevens's dissent. Boy Scouts, 530 U.S. at 663 (Stevens, J., dissenting). Justice Stevens began his dissent by alluding to Justice Louis Brandeis's maxim that a "single courageous State may, if its citizens choose, serve as a laboratory; and try novel social and economic experiments without risk to the rest of the country." Id. at 644 (quoting New State Ice Co. v. Liebmann, 285 U.S. 262, 311 (1932) (Brandeis, J., dissenting)). Justice Stevens concluded that New Jersey exemplified the "courageous" state to which Justice Brandeis referred and, therefore, the Supreme Court should not prevent or deter the elimination of discrimination on the basis of sexual orientation. Erica L. Stringer, Has the Supreme Court Created a Constitutional Shield for Private Discrimination Against Homosexuals? A Look at the Future Ramifications of Boy Scouts of America v. Dale, 104 W. VA. L. Rev. 181, 196 (2001) (citing Boy Scouts, 530 U.S. at 664 (Stevens, J., dissenting)).

153. Boy Scouts, 530 U.S. at 695 (Stevens, J., dissenting) (emphasis omitted).

The only apparent explanation for the majority's holding, then, is that homosexuals are simply so different from the rest of society that their presence alone-unlike any other individual's-should be singled out for special First Amendment treatment. Under the majority's reasoning, an openly gay male is irreversibly affixed with the label "homosexual." That label, even though unseen, commumicates a message that permits his exclusion wherever be goes. His openness is the sole and sufficient justification for his ostracism. Though unintended, reliance on such a justification is tantamount to a constitutionally prescribed symbol of inferiority.

Id. at 696; see also Koppelman, supra note 150, at 1823.

154. Boy Scouts, 530 U.S. at 664-65 (Stevens, J., dissenting) (quoting Roberts, 468 U.S. at 626).

155. Id. (quoting Roberts, 468 U.S. at 622). Justice Stevens also challenged the propriety of the majority's message-based conclusions and the Boy Scouts' asserted values by pointing out that Dale was an exemplary member of the organization for more than twelve years, had attained the rank of Eagle Scout (an honor accorded to only 3 percent of all members), and had been selected to be Assistant Scoutunaster. See id. at 665 . It was only after Dale revealed his hoinosexuality that the Boy Scouts revoked his membership. Id.; see also Stringer, supra note 152, at 196. 
majority's decision converted "the right of expressive association into an easy trump of any antidiscrimination law." ${ }^{156}$ The Boy Scouts Court did not raise the fundamental question of whether a charitable organization's right of expressive association might "trump" an IRS determimation that the organization no longer meets the definition of "charitable" under section 501(c)(3) due to its discrimmatory practices. ${ }^{157}$

To date, the Supreme Court has not addressed whether denying or revoking an organization's tax-exempt status based on its discriminatory membership policy or other exclusionary practice violates that organization's First Amendment right to expressive association. ${ }^{158}$ While the Court has sustained limitations on other First Amendment rights of charitable organizations as a condition to tax exemption under section 501(c)(3), ${ }^{159}$ it is ambiguous whether the Court would similarly conclude that an orgarization's constitutional right to expressive association would not be seriously constrained by an exemption revocation or denial. ${ }^{160}$ On the other hand, in light of the current political clinate, it seems clear that the government would argue that no compelling governmental interest exists to eradicate discrimination based on sexual orientation. Because the public-policy doctrine lacks a clearly defined scope of applicability, the IRS has effectively sanctioned such discrimination by charitable organizations through the current income-tax law.

\section{Alternative Proposals for Combating DISCRIMINATION BY CHARITABLE ORGANIZATIONS}

A pioneering scholar on the convergence of federal income-taxexemption law addressing racial discrimination, Brennen has analyzed and advocated potential solutions to the discrimination problem. Each

156. Boy Scouts, 530 U.S. at 701-02 (Souter, J., dissenting).

157. For a more thorough discussion of Boy Scouts implications with respect to the right of organizations to discriminate, see Andrew Koppelman, Should Noncommercial Associations Have an Absolute Right to Discriminate?, 67 LAw \& Contemp. Probs. 27 (2004); cf. Dale Carpenter, Expressive Association and AntiDiscrimination Law after Dale: A Tripartite Approach, 85 MinN. L. Rev. 1515, 1517 (2001).

158. Brennen, supra note 134 , at 843 .

159. For instance, the Court has upheld statutory limitations under section 501(c)(3) on charitable organizations' lobbying and political campaign activities. See infra notes 253-62 and accompanying text.

160. Brennen, supra note 11934, at 843-44 ("The Supreme Court has never addressed . . . whether it is constitutional to require an organization to forego its constitutionally protected freedon of expressive association . . to obtain or maintain a 501(c)(3) tax-exemption."). 
of these proposed solutions has its strengths and weaknesses, and, therefore, provides valuable insights in formulating this Article's proposal.

\section{A. The Public-Policy Doctrine: Clarification and Expanded Scope?}

In analyzing the public-policy doctrine announced in Bob Jones University, Brennen ultimately concluded that the judicially created doctrine is not the proper vehicle to combat racial discrimination and that the IRS is likely not the proper administrative agency to interpret and enforce it. ${ }^{161}$ In evaluating options to better apply, and achieve the purposes of, the public-policy doctrine, he suggested its codification to provide the necessary statutory authority for effective application to charitable organizations. ${ }^{162} \mathrm{He}$ also advocated for congressional authorization of a federal agency other than the IRS to "review and rule upon complaints of discrimination by tax-exempt charities," arguing that other agencies are better equipped to address such issues. ${ }^{163}$

Brennen has also argued that the IRS's almost exclusive reliance on constitutional-law principles in determining the boundaries of "established public policy" is inappropriate. ${ }^{164}$ While observing that the public-policy doctrine originates in the Internal Revenue Code and is therefore a statutory, not constitutional, principle, he argued that charities are usually private, not state, actors; thus, they are generally not subject to constitutional-law limitations like the Equal Protection Clause of the Fourteenth Amendment. ${ }^{165}$ Brennen subsequently proposed that the IRS "could engage in a type of analysis that considers a variety of sources constitutional, non-constitutional, federal and nonfederal-in deciding if a particular charity is in violation of 'established public policy." "166

Although Brennen's critique of the public-policy doctrine and how its inherent flaws prevent effective combat of discrimination by charitable organizations is persuasive, none of his proposed solutions appear to adequately address its problems. While the doctrine has been successful im eradicating racial discrimination in education, the lack of a clearly defined source of "established public policy" and the significant evidentiary burden placed on the IRS to determine and prove that an organization's principles violate public policy have rendered the

161. See Brennen, Racial Discrimination, supra note 30, at 446 .

162. See id.

163. Id.

164. Brennen, supra note 11934 , at 848 .

165. See id.

166. Id. at 849 . 
doctrine woefully inadequate in combating other forms of discrimination. In terms of marital-status or sexual-orientation discrimination, reliance on the doctrine is futile because such discrimination does not violate any "established" public policy. Although scholars have posited the existence of a national public policy against discrimination on the basis of sexual orientation, ${ }^{167}$ the current political climate renders such a conclusion questionable. ${ }^{168}$ In fact, the doctrine's potential response to the whims of the political climate is a fatal flaw. ${ }^{169}$ Despite these issues and extensive criticism by legal scholars, Congress has failed to provide a statutory remedy to the doctrine's deficiencies. As such, the public-policy doctrine-as it currently exists-is clearly not the best solution to eradicate the continued problem of discrimination by charitable organizations.

\section{B. Expanding Civil-Rights Laws' Applicability to Charitable Organizations}

\section{AN OVERVIEW OF THE EXPANSION APPROACH}

In addition to his scholarship on the public-policy doctrine, Brennen has also explored the expansion of the scope of civil-rights laws as a means to combat discrimination by charitable organizations. ${ }^{170}$ Although this expansion approach possesses inore potential than any proposals based on the public-policy doctrine, it still fails to provide a comprehensive solution to the kinds of discrimination illustrated in this Article.

167. See, e.g., Brennen, Tax Expenditures, supra note 30, at 184; HoPKINS, supra note $55, \S 5.4$, at 125 .

168. See, e.g., Aamer Madhani, Don't Drop "Don't Ask, Don't Tell," Pace Says, CHI. TRIB., Mar. 13, 2007, at C1 (discussing General Peter Pace's comments that homosexual acts "are immoral."); Peter Baker, Bush Re-Enters Gay Marriage Fight, WASH. Post, June 3, 2006, at A4; Elisabeth Bumiller et al., Bush Says Iraqis Will Want G.I. 's to Stay to Help, N.Y. TimES, Jan. 28, 2005, at A1 ("[President Bush] said that while "children can receive love from gay couples," he believed that "studies have shown that the ideal is where a child is raised in a married family with a man and a woman."); Bush Vows No Compromise In Opposing Same-Sex Marriage, WaSH. Post, Aug. 3, 2003, at A3; Dana Milbank, Charity Cites Bush Help in Fight Against Hiring Gays, WASH. POST, July 10, 2001, at A1.

169. In his Bob Jones University concurrence, Justice Powell cautioned that conforming an organization's aetivities to established government policy "ignores the important role played by tax exemption in encouraging diverse, indeed often sharply conflicting, activities and viewpoints." Bob Jones Univ. v. United States, 461 U.S. 574, 609 (1983) (Powell, J., concurring).

170. See Brennen, Tax Expenditures, supra note 30, at 169. 
Although a citizen's civil rights are protected by a federal "framework of laws consisting of the Constitution, statutes, regulations, executive actions, and court interpretation," these laws do not apply comprehensively to any violator of such rights. ${ }^{171}$ For instance, civilrights protection afforded by the Constitution does not normally apply unless the violator is a "state actor" - a term which generally does not include charitable organizations. ${ }^{172}$ Although some federal statutes subject private actors, including charitable organizations, to civil-rights limitations, ${ }^{173}$ some of these statutes only apply if the private actor receives "federal financial assistance" (FFA). ${ }^{174}$ Brennen's expansion approach focused on those civil-rights statutes containing an FFA requirement. ${ }^{175}$

These statutes generally contain enforcement mechanisms, which compel the awarding governmental agency to promulgate regulations that implement the statute's objectives, including a definition of FFA. ${ }^{176}$

171. See id. at 179-80.

172. See id. There are limited circumstances in which a charitable organization might be deemed a "state actor." See id. at 179 n.51. Like Brennen, however, this Article focuses on charitable organizations as private actors.

173. See id. at 179-80 \& n.52; see also The Americans with Disabilities Act of 1990, 42 U.S.C. $\S \S 12101-213$ (2000); The Age Discrimination in Employment Act, 29 U.S.C. \$ 621 (2000). Also, under 42 U.S.C. section 1983 (2000), private actors that are operating "under color of state law" may be subject to various constitutional restrictions. As Brennen points out, however, a state civil-rights statute that applies to charitable organizations may be limited or invalidated by federal constitutional law. Brennen, Tax Expenditures, supra note 30, at 169.

174. Id. at 171. See, e.g., Title VI of the Civil Rights Act of 1964, 42 U.S.C. $\S 2000 d$ (2000); Title IX of the Education Amendments of 1972, 20 U.S.C. $\S 1681$ (a) (2000); Rehabilitation Act of 1973, 29 U.S.C. § 794(a) (2000).

175. Brennen, Tax Expenditures, supra note 30, at 192.

176. For example, Title VI of the Civil Rights Act provides as follows:

Each Federal department and agency which is empowered to extend Federal financial assistance . . . is authorized and directed to effectuate . . this title ... by issuing rules, regulations, or orders of general applicability which shall be consistent with achievement of the objectives of the statute authorizing the financial assistance in connection with which the action is taken.

42 U.S.C. $\$ 2000$ d-1; see also 20 U.S.C. $\$ 1682$ (applying nearly identical language to Title IX of the Education Amendments). The apparently standard regulation issued by federal agencies pursuant to section $2000 \mathrm{~d}-1$ states the following:

The term Federal financial assistance includes (1) grants and loans of Federal funds, (2) the grant or donation of Federal property and interests in property, (3) the detail of Federal personnel, (4) the sale and lease of, and the permission to use (on other than a casual or transient basis), Federal property or any interest in such property without consideration or at a nominal consideration, or at a consideration which is reduced for the purpose of assisting the recipient, or in recognition of the public interest to 
Regulations define FFA, in part, as a "grant, loan, or contract other than a contract of insurance or guaranty," 177 and courts have interpreted it in the context of these civil-rights laws. ${ }^{178}$ Essentially, FFA constitutes "funds received directly or indirectly from the federal government." 179 Thus, the government requires charitable organizations that receive direct assistance from the federal government in the form of grants or loans, or that receive fees from direct recipients of FFA, to comply with these civil-rights laws. ${ }^{180}$ To address the large number of charitable organizations that do not meet either requirement, Brennen traveled down the arduous path of determining whether such organizations may be deemed to receive FFA in the form of certain tax benefits-principally, the income-tax exemption for charitable organizations $^{181}$ and the income-tax deduction for people making contributions to such organizations. ${ }^{182}$ In his analysis, Brennen considers two district-court opinions that reached opposite conclusions as to whether tax exemption constitutes FFA. ${ }^{183}$

In McGlotten v. Connally, a district court determined that certain federal tax benefits-mainly in the form of exemptions and deductions for contributions-constituted FFA under Title VI of the Civil Rights Act of $1964 .{ }^{184}$ The plaintiff in McGlotten sought to enjoin the IRS from grantimg exemptions to nonprofit social clubs and fraternal organizations that excluded nonwhite individuals from their membership. ${ }^{185}$ In response to the plaintiff's arguments, ${ }^{186}$ the

be served by such sale or lease to the recipient, and (5) any Federal agreement, arrangement, or other contract which has as one of its purposes the provision of assistance.

45 C.F.R. $\$ 80.13(\mathrm{f})$ (2006) (Department of Health, Education and Welfare); accord 7 C.F.R. $\$ 15.2(\mathrm{~g})$ (2006) (applying nearly identical language to the Department of Agriculture).

177. 45 C.F.R. $\S 80.13(\mathrm{f})$; accord 7 C.F.R. $\$ 15.2(\mathrm{~g})$.

178. See Brennen, Tax Expenditures, supra note 30 , at $171 \& \mathrm{n} .10$; see also Grove City Coll. v. Bell, 465 U.S. 555 (1984) (holding that a college was a recipient of FFA because its students received federal grants); NCAA v. Smith, 525 U.S. 459 (1999) (holding that, even though its college and university members received FFA, the NCAA's receipt of dues from such institutions did not constitute FFA); Richard Foss v. Chicago, 817 F.2d 34 (7th Cir. 1987) (holding that, although the City of Chicago received federal funding, its fire department was not a recipient of FFA).

179. Brennen, Tax Expenditures, supra note 30, at 171.

180. Id. at 171-72; see also Grove City Coll., 465 U.S. at 563; Smith, 525 U.S. at $465-69$.

181. I.R.C. $\$ 501$ (a) (2000).

182. I.R.C. $\$ 170(\mathrm{a})(1)$.

183. See Brennen, Tax Expenditures, supra note 30, at 200-07.

184. 338 F. Supp. 448 (D.D.C. 1972).

185. Id. at 450. Section 501(c)(7) exempts nonprofit social clubs that are "organized for pleasure, recreation, and other nonprofitable purposes, substantially all 
McGlotten court ultimately concluded that the tax benefits granted to fraternal organizations under section 501(c)(8) did constitute FFA under Title VI. ${ }^{187}$ In the absence of convincing legislative history, the court relied on Title VI's "plain purpose" of "eliminat[ing] discrimination in programs or activities benefitting from federal financial assistance." 188

The McGlotten court, however, also determined that the exemption granted to nonprofit social clubs under section 501(c)(7) did not constitute FFA. ${ }^{189}$ The court reasoned that such exemption, "limited as it is to member-generated funds and available regardless of the nature of the activity of the particular club, does not operate as a 'grant' of Federal funds," and thus was not covered by Title VI. ${ }^{190}$ According to the court, Congress had determined that membergenerated funds should not be taxed because they are merely "shifted from one pocket to another, both within the same pair of pants. Thus the exclusion of member generated revenue reflects a determination that as to these funds the organization does not operate as a separate entity." 191 In other words, McGlotten determined that social clubs do not function as entities separate and apart from their members. ${ }^{192}$

Finally, the court reasoned that, because the IRS granted the club a section 501(c)(7) exemption regardless of its activities, "there is no mark of Government approval inherent in the designation of a group as exempt. Congress has simply chosen not to tax a particular type of revenue because it is not within the scope [of income] sought to be taxed by the statute." ${ }^{193}$ The court reached the opposite conclusion with respect to fraternal organizations because their tax exemption "operates

of the activities of which are for such purposes and no part of the net earnings of which inures to the benefit of any private shareholder." I.R.C. $\$ 501$ (c)(7). Section 501(c)(8) exempts fraternal organizations "operating under the lodge system or for the exclusive benefit of the members of a fraternity itself operating under a lodge system . . . and providing for the payment of life, sick, accident, or other benefits to the members of such society, order, or association or their dependents." Id. §501(c)(8). Section $170(c)(4)$ authorizes a deduction for contributions to fraternal organizations that are "used exclusively for religious, charitable, scientific, literary or educational purposes." Id. § $170(\mathrm{c})(4)$.

186. The plaintiff's three arguments were as follows: (1) the Internal Revenue Code's grant of certain tax benefits is unconstitutional, (2) the Code does not authorize such benefits, and (3) such benefits constitute FFA under Title VI of the Civil Rights Act of 1964. McGlotten, $338 \mathrm{~F}$. Supp. at 450.

187. See id. at 461-62.

188. Id. at 461 .

189. Id. at 462

190. Id. at $457-59,462$.

191. Id. at 458 .

192. Brennen, Tax Expenditures, supra note 30, at 202 (citing McGlotten, 338 F. Supp. at 458).

193. McGlotten, 338 F. Supp. at 458. 
in fact as a subsidy in favor of the particular activities these groups are pursuing," 194 and was not "simply a way of defining taxable income." ${ }^{195}$ Thus, under McGlotten, a tax benefit will likely constitute FFA if Congress intended the benefit to constitute more than an "income-defining provision" and if the grant of the benefit is conditional on the benefiting organization limiting its activities to certain "government-specified purposes." 196

Contrary to McGlotten, the federal district court in Bachman $v$. American Society of Clinical Pathologists concluded that tax exemption alone did not constitute FFA for purposes of section 504 of the Rehabilitation Act of 1973. ${ }^{197}$ In Bachman, the plaintiff sued the American Society of Clinical Pathologists, alleging that the organization's denial of her request for special testing conditions constituted discrimination against a handicapped person in violation of the Act. ${ }^{198}$ Although the Society received no direct funding from the federal government, the plaintiff contended that it received "indirect financial assistance" in the form of its tax-exempt status. ${ }^{199}$

The court stated that, "[a]lthough tax exeinpt status confers a substantial economic advantage on [the Society], not every item of economic value granted by the federal government counts as financial assistance." ${ }^{200}$ Relying on the "plain meaning" of the statute, the court concluded that "[t]he term 'assistance' connotes a transfer of government funds by way of subsidy, not merely an exemption from taxation." 201 In addition, the Bachman court also looked to cases, like Grove City College v. Bell, in which courts have applied Title IX based

194. Id. at 462.

195. Brennen, Tax Expenditures, supra note 30, at 203 (citing McGlotten, 338 F. Supp. at 462).

196. Id. at 203-04.

197. 577 F. Supp. 1257, 1264 (D.N.J. 1983).

198. Id. at 1258 .

199. See id. at 1263. Although the Society was not receiving FFA at the time of the lawsuit, it nevertheless conceded that it received two grants from the Department of Health, Education and Welfare during the period in which the plaintiff applied to take the examination. See id. at 1260 . The court, however, determined that the plaintiff was not subject to discrimination under the program or activity for which the FFA was received. See id. at 1263 ("[T]he receipt of federal financial assistance by a multiperson entity, for specific application to certain programs or activities, does not, without more, bring all of those multiple programs or activities within the reach of section 504." (quoting Brown v. Sibley, 650 F.2d 760, 767 (5th Cir.1981))).

200. Id. at 1263 .

201. Id. at 1264. 
on the educational institution's receipt of federal grants and student loans-not its tax-exempt status. ${ }^{202}$

Because Brennen advocated a more expansive application of the civil-rights laws to charitable organizations, he concluded that the broader interpretation of FFA in McGlotten and Grove City College was "the preferred method of interpretation in terms of maximizing protections to those persons whose federal civil rights are violated."203 Brennen argued that parties to a civil-rights suit would expend more time determining whether discrimination has occurred rather than discerning whether the organization had received the correct form of governmental assistance. ${ }^{204}$ Notwithstanding the social-justice implications of a broader view of FFA, Brennen acknowledged that the lack of a Supreme Court decision specifying that certain tax benefits constitute FFA allows courts, like the Bachman court, to interpret the term narrowly and decline to impose civil-rights constraints on "nontraditional defendants." 205 Brennen reasoned that, if the tax benefit received by the defendant organization in Bachman was in the form of a government grant or loan, the plaintiff would have likely succeeded in her Rehabilitation Act claim. ${ }^{206}$

Other than its general interpretation of FFA under the civil-rights laws, the Supreme Court has not specifically considered whether certain

202. Id. at 1264-65 (citing Grove City Coll., 687 F.2d 684). Brennen has argued that the Bachman court's narrow interpretation of FFA is "clearly at odds" with the broader notion espoused by the Supreme Court in Grove City Coll., in which the Court stated that

[n]othing in [Title IX] suggests that Congress elevated form over suhstance by making the application of the nondiscrimination principle dependent on the manner in which a program or activity receives federal assistance. There is no hasis in [Title IXl for the view that only the institutions that themselves apply for federal aid or receive checks directly from the Federal Government are subject to regulation. As the Court of Appeals observed, "by its all inclusive terminology [Title IX] appears to encompass all forms of federal aid to education, direct or indirect."

Brennen, Tax Expenditures, at 206 (quoting Grove City Coll., 465 U.S. at 564); see also Galvin \& Devins, supra note 34, at 1375 (citing Boris I. Bittker \& Kenneth M. Kaufman, Taxes and Civil Rights: "Constitutionalizing" the Internal Revenue Code, 82 YALE L.J. 5I, 62 (1972) (observing that the "tax-subsidy rationale" employed in McGlotten "has implications beyond the area of racial restrictions" and that subsidies could include exemptions from federal taxes other than income tax)).

203. Brennen, Tax Expenditures, supra note 30, at 207.

204. See id.

205. See id. Brennen defined "nontraditional defendants" as "those civil rights defendants who are not state actors and who do not receive traditional forms of FFA like government loans or grants." Id. at 207 n. 206.

206. Id. at 207. 
tax benefits like tax exemption constitute FFA. ${ }^{207}$ The Court has, however, concentrated on the related issue of whether certain tax benefits should be considered government expenditures or government neutrality for constitutional-law purposes-that is, the well-known "tax expenditure" theory in federal income-tax law. ${ }^{208}$

The primary question addressed by the tax-expenditure theory is whether the receipt of a tax benefit should be legally regarded as equivalent to a direct government grant of money. ${ }^{209}$ Under the theory, an organization's section 501(c)(3) tax exemption is equivalent to a direct government outlay of cash. ${ }^{210}$ Similarly, the tax-expenditure theory treats the amount of a charitable-contributions deduction as equivalent to a direct government grant of money to the taxpayer claiming the deduction. ${ }^{211}$

The theory's equivalency "applies only to tax benefits enacted to implement social policy-not those intended as a further delineation of

207. Id. at 173; cf. Walz v. Tax Comm'n, 397 U.S. 664 (1970).

The grant of a [state propertyl tax exemption is not sponsorship since the government does not transfer part of its revenue to churches but simply abstains from demanding that the church support the state. No one has ever suggested that tax exemption has converted libraries, art galleries, or hospitals into arms of the state or put employees "on the public payroll." There is no genuine nexus between tax exemption and establishment of religion.

Id. at 675.

208. See Brennen, Tax Expenditures, supra note 30, at 173, 208; see also infra note 215 .

209. Brennen, Tax Expenditures, supra note 30, at 208-09 (citing STANLEY S. SurRey, Pathways to TAX ReForm: THE CONCEPT OF TAX EXPENDITURES 6-7, 30-49 (1973); Stanley S. Surrey \& Paul R. MCDaniel, Tax Ex penditures 1-30 (1985)).

The federal . . . tax system consists . . . of two parts: one part comprises the structural provisions necessary to impleinent the income tax . . . ; the second part comprises a system of tax expenditures under which . . . financial assistance programs are carried out through special tax provisions rather than through direct Government expenditures.

Id. at 210 n.214 (quoting SURREY, supra, at 6).

210. Brennen, Tax Expenditures, supra note 30, at 209. Courts have sometimes reached the same conclusion. For example, in Regan $v$. Taxation with Representation of Washington, the Court held the following:

Both tax exemptions and tax deductibility are a form of subsidy that is administered through the tax system. A tax exemption has much the same effect as a cash grant to the organization of the amount of tax it would have to pay on its incoine. Deductible contributions are similar to cash grants of the amount of a portion of the individual's contributions.

461 U.S. 540, 544 (1983); see also Walz, 397 U.S. at 699 (Harlan, J., concurring) ("[E]xemptions do not differ from subsidies as an economic matter.").

211. Brennen, Tax Expenditures, supra note 30, at 209. 
the appropriate tax base." 212 For instance, when the McGlotten social club received tax benefits, those benefits would not be equated with a government grant or loan because the club's exemption was not intended to effect any social policy. ${ }^{213}$ Rather, the government simply chose not to tax that particular revenue stream. ${ }^{214}$ Accordingly, under the tax-expenditure theory, a tax benefit that accomplishes a social purpose and a direct government outlay for the identical purpose are equivalent-for both economic and constitutional-law purposes. ${ }^{215}$

Although Brennen primarily accepted the economic-equivalence concept contained in the tax-expenditure theory to support his thesis, he appeared to join other scholars in limiting its impact in the constitutional-law context. ${ }^{216} \mathrm{He}$ contended that the application of economic equivalence to federal civil-rights law differs from application to constitutional law. ${ }^{217}$ For example, federal or state involvement is crucial in determining whether a First Amendment violation occurs due to government funding. Such involvement is less critical, however, in applying federal civil-rights laws, in which the primary inquiries focus on whether the existence of government funding to a private individual or entity is significant and "whether Congress intended that the financial benefit support the private party's activities." ${ }^{18}$ Brennen ultimately concluded that "tax expenditure theory can and should be used to equate tax benefits received by charities with government grants

212. Id. at 209-10 (citing SURREY, supra note 209, at 6).

213. Id. at 227.

214. See id.; see also supra notes 19189-92 and accompanying text.

215. Brennen, Tax Expenditures, supra note 30, at 210 . For example, while a church's income-tax exemption may be economically equivalent to the receipt of a direct government grant under the tax-expenditure theory, the two benefits may not be similarly permissible under constitutional-law principles. The direct government grant may be seen as violating the Establishment Clause, whereas the government's grant of a tax exemption may be seen as neutral, and thus constitutionally permissible. See Walz, 397 U.S. at $674-76$ (holding that an exemption from state property tax for property owned by churches and used solely for religious worship did not violate the Establishment Clause). The Court characterized such exemptions as "benevolent neutrality" that neither advanced nor inhibited religion and created only a minimal and remote "entanglement" between church and state. See id.

216. See Brennen, Tax Expenditures, supra note 30, at 210 (citing Edward A. Zelinksy, Are Tax "Benefits" Constitutionally Equivalent to Direct Expenditures?, 112 HaRV. L. ReV. 379 (1998); Linda Sugin, Tax Expenditure Analysis and Constitutional Decisions, 50 Hastings L.J. 407 (1999)).

217. See id. at 224.

218. Id.; see also Galvin \& Devins, supra note 34, at 1376 ("[A] tax exemption might be permissible under the establishment clause but impermissible under the Civil Rights Act of 1964."). 
and loans received by various private parties." ${ }^{219}$ In other words, a charitable organization's income tax exemption should constitute FFA for purposes of subjecting that organization to federal civil-rights laws.

\section{CRITIQUE OF THE EXPANSION APPROACH}

While Brennen's expansion approach is undeniably persuasive and viable, the proposal's very weakness is its reliance on civil-rights laws to combat ongoing discrimination by charitable organizations. Current civil-rights laws have limited application, as they only protect against discrimination on the basis of race, color, national or ethnic origin, religion, sex, age, and disability. These do not prohibit discrimination on the bases of sexual orientation ${ }^{220}$ or marital status ${ }^{221}$-both of which appear to be common forms of discrimination currently engaged in by charitable organizations. ${ }^{222}$ Although Brennen referred to discrimination on the basis of sexual orientation as "harmful discriminatory behavior, $" 223$ he failed to further explain how his proposal to expand the application of civil-rights laws would combat this behavior. Moreover, Brennen's proposal confronts an additional hurdle by relying on a more expansive interpretation of FFA. The Supreme Court, however, has not determined that FFA should include tax benefits, and lower courts are

219. Brennen, Tax Expenditures, supra note 30, at 224-25; see also Galvin \& Devins, supra note 342 , at 1378 n.118 ("[T]ax exemptions are government aid for purposes of the 1964 Civil Rights Act.").

220. See, e.g., Simonton v. Runyon, 232 F.3d 33, 35 (2d Cir. 2000) ("Although congressional inaction subsequent to the enactment of a statute is not always a helpful guide, Congress's refusal to expand the reach of Title VII is strong evidence of congressional intent in the face of consistent judicial decisions refusing to interpret 'sex' to include sexual orientation."); Wrightson v. Pizza Hut of Am., Inc., 99 F.3d 138, 143 (4th Cir. 1996) ("Title VII does not afford a cause of action for discrimination based upon sexual orientation."); Williamson v. A.G. Edwards \& Sons, Inc., 876 F.2d 69, 70 (8th Cir. 1989) ("Title VII does not prohibit discrimination against homosexuals."); DeSantis v. Pac. Tel. \& Tel. Co., 608 F.2d 327, 329-30 (9th Cir. 1979) ("Title VII's prohibition of 'sex' discrimination applies only to discriınination on the basis of gender and should not be judicially extended to include sexual preference such as homosexuality.").

221. See, e.g., Coleman v. B-G Maint. Mgmt. of Colo., Inc., 108 F.3d 1199, 1204 (10th Cir. 1997) ("Title VII prohibits enployers from treating married women differently than married men, but it does not protect marital status alone."); Fisher v. Vassar Coll., 70 F.3d 1420, 1447 (2d Cir. 1995) ("[Mlarital status alone is not a ground for bringing a suit under Title V1I."); Cleaves v. City of Chicago, 68 F. Supp. 2d 963, 967 (N.D. Ill. 1999).

222. See supra notes $14-28$ and accompanying text. Unless reported in the press or discussed in a court decision, the type and frequency of alleged or actual discrimination by charitable orgamizations cannot be verified.

223. See Brennen, Tax Expenditures, supra note 30, at 169. 
not in agreement, as illustrated by the decisions in McGlotten and Bachman. $^{224}$

Until the Supreme Court rules on these issues directly, the use of civil-rights laws to combat discrimination fails to comprehensively address the problem. Furthermore, the canons of statutory interpretation lend credence to the argument that, if Congress intended to extend the nondiscrimination provisions in the civil-rights laws to charitable organizations, it would have done so by including specific language in the statutes or by directing the promulgation of administrative rcgulations. ${ }^{225}$ As stated by the Second Circuit Court of Appeals in a case attempting to expand civil-rights protection granted by Title VII, Congressional inaction can be "strong evidence of congressional intent."226

Unfortunately, despite the merits of Brennen's proposal, it does not reflect current reality. Even if courts interpreted FFA broadly enough to encompass tax benefits, such as exemption and the charitable contributions deduction, current civil-rights laws would not prohibit charitable organizations from discriminating on the basis of sexual orientation and marital status. To truly abolish discrimination by charitable organizations, Congress needs to expand these laws to expressly prohibit discrimination on such bases. Congressional intent must exist to prohibit this discrimination by all private actors, but such intent is dubious at best. A specific legislative response could prove to be more effective in preventing federal public monies from being utilized by charitable organizations to discriminate against classes of citizens.

\section{AMENDMENT OF SECTION 501(C)(3) TO ESTABLISH A NONDISCRIMINATION REQUIREMENT FOR TAX EXEMPTION}

Federal income-tax law does not explicitly address or proscribe the ostensibly common practice of discrimination by charitable organizations. $^{227}$ The only possible restraint on discrimination exists in the public-policy doctrine established by Bob Jones University, which is riddled with limitations, including the lack of a clearly defined source of "established public policy." 228 Current civil-rights laws are also limited in their application and do not prohibit the seemingly common

224. See supra notes I84 \& 20I and accompanying text.

225. See generally Title VI of the Civil Rights Act of 1964,42 U.S.C. $§ 2000 d$ (2006). This Article's proposal could be similarly criticized.

226. Simonton v. Runyon, 232 F.3d 33, 35 (2d Cir. 2000).

227. See supra notes 14-28, 3I and accompanying text.

228. See supra notes I 19-29 and accompanying text. 
bases of discrimination by charitable organizations-sexual orientation and marital status. ${ }^{229}$ Accordingly, the existing deficiencies in current federal law effectively sanction most discrimination by charitable organizations.

\section{A. The Nondiscrimination-Requirement Proposal}

In light of these problems, it seems that the most effective and comprehensive solution to eliminate discrimination by charitable organizations is the enactment of a broad and well-defined nondiscrimination requirement in section 501(c)(3). Inherent in this proposal is the notion that any discrimination by a charitable organization is intrinsically inconpatible with that organization's charitable purpose and mission. This nondiscrimination provision should be based on currently existing language in the civil-rights laws, but should be expanded to include the bases on which charitable organizations most commonly discriminate. Because the provision appears in a federal income-tax-exemption statute, Congress may be more open to such an expanded prohibition because its applicability would be limited to nonprofit organizations-not for-profit, private actors. Congress could institute this proposal by adding a subparagraph to section 501(c)(3) similar to the following:

No organization described under subsection (c)(3) shall exclude from participation in, deny the benefits of, or subject to discrimination under, any of its progranıs or activities, including its employment practices, any person in the United States on the basis of race, color, national or ethnic origin, sex or gender, age, handicap, disability, religion, marital status, or sexual orientation. ${ }^{230}$

Many reasons support the proposal set forth above. By not relying on an ill-defined public-policy doctrine or the questionable applicability of the civil-rights laws, a nondiscrimination requirement in section 501(c)(3) offers a more comprehensive solution. Furthermore, by setting forth the requirement directly in the statute that grants taxexempt status, Congress would send a strong message to potential and existing charitable organizations that discriminatory policies and practices are fundamentally inconsistent with a tax-exempt status under

229. See supra notes $220-22$ and accompanying text.

230. See infra note 325 and accompanying text for possible exceptions to this nondiscrimination requirement. This proposed text is not intended to be so specific that it implicitly excludes applicability to other types of discrimination. 
section 501(c)(3). Instead, nondiscriminatory practices and policies comport with the commonly accepted notion of being "charitable" and conferring public benefit. ${ }^{231}$

More importantly, a statutory prohibition on discrimination would transform section 501(c)(3) into the "gold standard" for all organizations exempt from federal income tax. Because a corresponding benefit of a section 501(c)(3) tax exemption is the ability to provide donors with a charitable-contributions deduction under section $170,{ }^{232}$ such a transformation would ensure that the charities' beneficiaries are as diverse and all encompassing as the taxpaying public from which such organizations draw their support. In other words, the flow of taxdeductible dollars generated by section 170 should not be used to discriminate against a particular segment of society because the significant cost of providing such tax benefit-estimated to be $\$ 232$ billion over the next five years-is borne by all taxpayers. ${ }^{233}$

In line with these arguments, the IRS's grant of a section 501(c)(3) tax-exempt status arguably creates a social contract between the organization, the government, and taxpayers. Although this socialcontract concept alone does not constitute a legally enforceable obligation, ${ }^{234}$ it suggests that there are certain purposes and activities that society attributes to a "charitable" organization. In contrast, some actions-such as discrimination-do not comport with society's notion of what constitutes a charity and, thus, violate or undermine this social contract. A charitable organization's violation could cause a shift in the

231. See supra note 128 and accompanying text (arguing that a federal public policy against discrimination on the basis of sexual orientation or marital status either already exists or is currently evolving). See generally Johnny Rex Buckles, The Community Income Theory of the Charitable Contributions Deduction, 80 IND. L.J. 947, 977 (2005) ("[C]haritics primarily produce community income. In theory, charities exist for no reason other than to benefit the community.").

232. See supra note 41 and accompanying text.

233. See OFFICE OF MGMT. \& BUDGET, supra note 2, at 291 tbl.19-2; see also andrew Chamberlain \& Mark Sussman, Tax Found., Special Report No. 137, Charities and Public Goods: The Case for Reforming the Federal Income Tax DEDUCTION FOR CHARITABLE GIFTS 7 (2005), http://www.taxfoundation.org/ files/sr137.pdf ("The charitable deduction shifts part of the cost of private charitable giving onto the rest of society.").

234. Social-contract theory should not be equated with assertions made by litigants in recent cases that an "express or implied contract arises between an organization and the federal government" upon the granting of exempt status under section 501(c)(3). HoPKINS, supra note 55, \& 5.5(g) (Supp. 2006) ("The principal contention in this regard has been that tax exemption accorded to hospitals gives rise to a contract obligating the exempt hospital to provide medical care to uninsured patients without regard to their ability to pay for the care. This assertion, however, has been uniformly rejected." (citations omitted)). Similarly, tax exemption does not create thirdparty beneficiaries to any such implied contract. Id. $\$ 5.5(\mathrm{~h})-(\mathrm{i})$. 
public's perception and support, leading to a decrease in the receipt of donations and other financial support. For instance, the United Way of the National Capital Area's publicized financial scandal ${ }^{235}$ and the Boy Scouts of America's exposed ban on homosexual members caused both organizations to suffer adverse financial consequences. ${ }^{236}$ Finally, the Supreme Court alluded to the existence of a social contract in explaining its expansive view of "charitable" under section 501(c)(3) in Bob Jones University:

When the Government grants exemptions or allows deductions all taxpayers are affected; the very fact of the exemption or deduction for the donor means that other taxpayers can be said to be indirect and vicarious "donors." Charitable exemptions are justified on the basis that the exempt entity confers a public benefit-a benefit which the society or the community may not itself choose or be able to provide, or which supplements and advances the work of public imstitutions already supported by tax revenues. History buttresses logic to make clear that, to warrant exemption under [section] 501(c)(3), an institution must fall within a category specified in that section and must demonstrably serve and be in harmony with the public interest. The institution's purpose must not be so at odds with the common community conscience as to undermine any public benefit that might otherwise be conferred. ${ }^{237}$

As demonstrated by the social-contract concept, discrimination is at odds with the common community conscience and the notion of what constitutes a charity; therefore, it undermines any public benefit that

235. See Jacqueline L. Salmon, Area United Way's Ex-Chief Admits $\$ 500,000$ Fraud, WASH. POST, Mar. 5, 2004, at B1.

236. See, e.g., Brad Wolverton, D.C. United Way Leader Sentenced to Jail Time, CHRON. OF PHILANTHROPY, May 17, 2004, http://philanthropy.com/free/update/ 2004/05/2004051701.htm (noting that the United Way of the Capital Area received only $\$ 38$ million in private donations during fundraising campaign of 2003 to 2004, compared to $\$ 90$ million in 2001); Robert Strauss, They're Mad as Hell, and They're Not Making Donations Anymore, N.Y. TIMES, Nov. 17, 2003, at F17 (reporting that the United Way of Southeastern Pennsylvania discontinued its funding of Boy Scouts' inner-city program because of the organization's discriminatory policy towards homosexuals); Steve Barnes, Texas: A United Way and Boy Scouts Part Company, N.Y. TIMES, Nov. 14, 2003, at A18 (reporting that the United Way of Austin eliminated its annual funding of the local Boy Scouts because the of the Boy Scouts' exclusion of gay youths).

237. Bob Jones Univ. v. United States, 461 U.S. 574, $591-92$ (1983) (citations oinitted). 
such charities otherwise confer. Accordingly, in light of such discriminatory practices or policies, these charities should no longer be considered "charitable" or receive tax exemptions under section 501(c)(3).

It is possible that narrowing the scope of section 501(c)(3) could result in a reduction in the number of organizations that qualify for taxexemptions. Nevertheless, with approximately 1.1 million organizations-with assets exceeding $\$ 1.9$ trillion $^{238}$-currently enjoying section 501(c)(3) tax exemptions, ${ }^{239}$ many commentators have proposed alternatives to the current tax-exemption scheme that could effectively limit the number of charitable organizations. ${ }^{240}$ Of course, "Such a position . . . would cut a very wide swath through current exempt organizations . . but it would end the current uncertainty." 241

238. Diane Freda, Latest IRS Statistics Show Assets of Charitable Organizations Increasing, DAILY TAX REP., Aug. 28, 2006, at G-5.

239. I.R.S., DeP'T OF THE TREasury, 2005 DATA BOOK 40 tbl.22 (2005), http://www.irs.gov/pub/irs-soi/05databk.pdf. The IRS granted section 501(c)(3) tax exemptions to 63,402 organizations in the 2005 fiscal year. $I d$. at 39 tbl.21. The total number of these exempt organizations exempt is actually larger than the 1.046 million reported by the IRS because "certain organizations, such as churches, integrated auxiliaries, subordinate units, and conventions or associations of churches, need not apply for recognition of tax-exemption, unless they specifically request a ruling." Id. at 40 n.1. In addition, the IRS does not require such organizations to file annual information returns. Id.

240. See, e.g., Thomas Kelley, Rediscovering Vulgar Charity: A Historical Analysis of America's Tangled Nonprofit Law, 73 FordHAM L. REv. 2437, 2491-92 (2005) (proposing a different definition of charity). Professor Thomas Kelley proposed dividing "charity" into two distinct categories: (1) a "vulgar" charity, "whose missions and resources are devoted exclusively to serving the poor," and which is subject to a permissive destination-of-income test so as to more liberally earn support for its cause, id. at 2490-91; and (2) nonvulgar charities that are currently regarded as "public benefit organizations" under section 501(c)(3). Id. at 2490.

Professor John Colombo argued that, in cases in which nonprofit entities provide "commercially similar" services to for-profit entities, as well as in other instances, the primary section 501(c)(3) criterion should be one of "enhancing access"-namely, whether the organization provides access to services to underserved populations, or services to the general population not otherwise provided by for-profit entities. John D. Colombo, The Role of Access in Charitable Tax Exemption, 82 WASH. U. L.Q. 343 (2004); see also Borek, supra note 63, at 222 (proposing the "decoupling" of the charitable-contributions deduction and exemption and the redefining of "charitable" from a "catch-all category of exempt activities not otherwise delineated" to a term "reserved for organizations the primary purpose of which is to benefit the poor"); Lars G. Gustafsson, The Definition of "Charitable" for Federal Income Tax Purposes. Defrocking the Old and Suggesting Some New Fundamental Assumptions, 33 Hous. L. REV. 587, 647 (1996) ("It is one thing for a society to recognize (and, in some cases to tolerate) an organization's existence; it is a far different matter to require society to financially support, even indirectly, that organization.").

241. Colombo, supra note 240 , at 386. 
Ultimately, if the IRS denies or revokes a section 501(c)(3) exemption due to a nondiscrimination violation, the offending organization may still qualify under section 501(c)(4) as a "social welfare" organization. ${ }^{242}$ Donations to social-welfare organizations, however, do not qualify for the charitable-contributions deduction under section $170 .{ }^{243}$ Nevertheless, this would prevent charitable organizations from using the tax-deductible dollars they receive to discriminate against nıembers of society.

\section{B. Difficulties and Potential Criticisms}

This nondiscrimination-requirement proposal should not preclude necessary discussion of the real problem of discrimination by charitable organizations. Rather, its purpose is to raise awareness and to offer a more comprehensive solution. Because it is a new legal concept, the nondiscrimination requirement may be difficult to apply to the existing tax-exempt-organization community.

\section{CONSTITUTIONALITY ISSUES}

One of the major criticisms of this proposal would likely mirror those lobbied against the New Jersey Supreme Court's decision in Dale v. Boy Scouts of America-namely, that a broad nondiscrimination

242. See, e.g., Regan v. Taxation with Representation of Wash., 461 U.S. 540, 544 (1983); Branch Ministries v. Rossotti, 211 F.3d 137, 143 (D.C. Cir. 2000). Section 501(c)(4)(A) grants tax-exempt status to

[c]ivic leagues or organizations not organized for profit but operated exclusively for the promotion of social welfare, or local associations of employees, the membership of which is limited to the employees of a designated person or persons in a particuIar municipality, and the net earnings of which are devoted exclusively to charitable, educational, or recreational purposes.

I.R.C. $\S 501(\mathrm{c})(4)(\mathrm{A})$ (2000). In upholding the section 501(c)(3) lobbying and politicaIcampaign restrictions, the Supreme Court relies heavily on the availability of an affiliated section 50I(c)(4) organization as an alternate means of communication. See supra notes 261-62; infra notes 279-80. This Article einploys the Court's reasoning to support the nondiscrimination-requirement proposal. One could argue, however, that discriminatory policies or practices conflict with the regulatory definition of social welfare:

An organization is operated exclusively for the promotion of social welfare if it is primarily engaged in proinoting in soine way the common good and general welfare of the people of the community. An organization embraced within this section is one which is operated primarily for the purpose of bringing about civic betterments and social improvements.

Treas. Reg. § 1.501(c)(4)-1(a)(2)(i) (as amended in 1990).

243. I.R.C. $\S 170(a)(1),(c)(1)-(2)$. 
requirement in section 501(c)(3) violates an organization's First Amendment rights, ${ }^{244}$ because it "would significantly affect . . . [an organization's] ability to advocate public or private viewpoints." 245 While the U.S. Supreme Court has not directly addressed this particular issue, ${ }^{246}$ it has upheld other restrictions on charitable organizations' activities as conditions to exemption under section 501(c)(3), and has dismissed claims that such restrictions violated an organization's First Amendment rights. ${ }^{247}$ It is important to note that that tax exemption is typically viewed as a congressional grant, not a constitutional right. ${ }^{248}$

In Regan $v$. Taxation with Representation of Washington, a nonprofit organization's stated mission was to promote what it perceived to be the "public interest" in the area of federal taxation. ${ }^{249}$ Two other nonprofit corporations-one of which had tax-exempt status under section 501(c)(3) and the other of which had tax-exempt status under section 501(c)(4)-merged to form Taxation With Representation of Washington (TWR) ${ }^{250}$ In denying TWR's application for exemption under section 501(c)(3), the IRS determined that a substantial part of TWR's activities would consist of attempting to influence legislation in violation of the "no substantial part" statutory limitation on lobbying activities. ${ }^{251}$ In addressing TWR's argument that the lobbying limitation violated its First Amendment rights, ${ }^{252}$ the Court first explained that "[b]oth tax exemptions and tax-deductibility are a form of subsidy that

244. See, e.g., Roy Whitehead, Jr. \& Walter Block, The Boy Scouts, Freedom of Association, and the Right to Discriminate: A Legal, Philosophical, and Economic Analysis, 29 OKLA. CITY U. L. Rev. 851, 882 (2004) ("Freedom of association is a necessary condition of a civilized order; laws prohibiting discrimination violate this freedom and must be repealed."); Erez Reuveni, On Boy Scouts and AntiDiscrimination Law: The Associational Rights of Quasi-Religious Organizations, 86 B.U. L. REv. 109, 113 (2006) (contending that "quasi-religious" organizations like the Boy Scouts deserve "greater associational protections" under the First Amendment than purely secular organizations); Christopher Ramey, Revealing the Inadequacy of AB17: How Dictating Moraility Upon Faith-Based Organizations Will Wreak Havoc on California's Economy, 26 T. JEFFERSON L. REV. 125 (2003) (criticizing California's proposed legislation which required employers with state contracts valued at $\$ 100,000$ or more to provide the same benefits to spouses and domestic partners of employees, because it imposed on the moral convictions of faith-based organizations that contracted with the State).

245. Boy Scouts of Am. v. Dale, 530 U.S. 640, 650 (2000).

246. See Brennen, supra note 134 , at 843.

247. See id. at 843-44.

248. See Christian Echoes Nat'l Ministry, Inc. v. United States, 470 F.2d 849, 857 (10th Cir. 1972).

249. 461 U.S. $540,541-42$ (1983).

250. See id. at 543.

251. Id. at 542 (citing 1.R.C. § 501(c)(3) (2000)).

252. See id. 
is administered through the tax system," analogizing such benefits to cash grants to the organization. ${ }^{253}$ The Court further clarified that "Congress chose not to subsidize lobbying as extensively as it chose not to subsidize other activities that nonprofit organizations undertake to promote the public welfare." 254

The Court agreed with TWR's assertion that "the government may not deny a benefit to a person because he exercises a constitutional right." ${ }^{255}$ It noted, however, that the Internal Revenue Code did not restrict TWR's ability to receive deductible contributions in support of its nonlobbying activities, ${ }^{256}$ but that "Congress has merely refused to pay for lobbying out of public moneys." 257 The Regan Court further rejected the "notion that First Amendment rights are somehow not fully realized unless they are subsidized by the State." 258

Significantly, the Regan Court reminded TWR that it still qualified for a tax exemption under section $50 \mathrm{I}(\mathrm{c})(4)$ as a social-welfare organization, and that it could obtain deductible contributions for its nonlobbying activities by returning to the dual structure from which it originated. ${ }^{259}$ The Court did, however, caution that TWR needed to ensure that the charitable organization did not subsidize the section

253. Id. at 544 .

254. Id. The Court also dismissed TWR's argument that the lobbying limitation violated its equal protection rights under the Due Process Clause. See id. at 542. Additionally, the Court found that it was rational for Congress to decide to subsidize lobbying by veterans' organizations, even though it chose not to subsidize substantial lobbying by other charities. See id. at 551. The Court explained that veterans bave "been obliged to drop their own affairs and take up the burdens of the nation," id. (quoting Boone v. Lightner, 319 U.S. 561, 575 (1943)), and that the United States has a long tradition of "compensating veterans for their past contributions by providing them with numerous advantages." Id. (citing Pers. Adın'r v. Feeney, 442 U.S. 256, 279 n. 25 (1979)).

255. Id. at 545 .

256. See id.

257. Id.; see also id. at 546 (citing Cammarano v. United States, 358 U.S. 498 (1959) (involving a Treasury Regulation that forbade business deductions for lobbying expenses)).

258. Id. at 546 (citing Cammarano, 358 U.S. at 515 (Douglas, J., concurring)).

The [charitable organization] may engage in [lobbying and politicalcanıpaign intervention] activities without restraint, subject, however, to withholding of the exemption or, in the alternative, the taxpayer may refrain from such activities and obtain the privilege of exemption. . . The taxpayer may opt to enter an area of federal employment subject to the restraints and limitations upon his First Amendment rights. Conversely, he may opt not to receive employment funds at the public trough in the areas covered by the restraints and thus exercise his First Ainendment rights unfettered.

Christian Echoes Nat'l Miristry, Inc. v. United States, 470 F.2d 849, 857 (1972). 259. Regan, 461 U.S. at 544. 
501(c)(4) entity, "otherwise, public funds might be spent on an activity Congress chose not to subsidize." 260

In his concurrence, Justice Harry Blackmun noted that "[section] 501(c)(3) organizations retain their constitutional right to speak and to petition the Government" and agreed with the majority that a section 501(c)(3) organization can preserve both its tax exemption and its free speech rights by utilizing an affiliated section 501(c)(4) organization to carry out its lobbying pursuits. ${ }^{261}$ Nevertheless, Justice Blackmun still cautioned that

[s]hould the IRS attempt to limit the control these organizations exercise over the lobbying of their 501(c)(4) affiliates, the First Amendment problems would be insurmountable. It hardly answers one person's objection to a restriction on his speech that another person, outside his control, may speak for him. . . . Similarly, an attempt to prevent [section] 501(c)(4) organizations from lobbying explicitly on behalf of their [section] 501(c)(3) affiliates would perpetuate [section] 501(c)(3) organizations' inability to make known their views on legislation without incurring the unconstitutional penalty. Such refusals would extend far beyond Congress' $[\mathrm{s}]$ mere refusal to subsidize lobbying. ${ }^{262}$

In other words, section 501(c)(4) provides a constitutional safety hatch when imposing restrictions on the activities and possible constitutional rights of charitable organizations. ${ }^{263}$ Less than two decades after Regan, the D.C. Circuit adopted this very approach in addressing a violation of the political-activities prohibition in section 501(c)(3). ${ }^{264}$ In Branch Ministries v. Rossotti, the plaintiff-a tax-

260. Id. To do so, the two entities should be "separately incorporated and keep records adequate to show that tax-deductible contributions are not used to pay for lobbying." Id. at 544 n.6.

261. Id. at 553 (Blackmun, J., dissenting).

262. Id.

263. Brennen has acknowledged that his proposal-expanding the applicability of federal civil-rights laws to charitable organizations-was not intended to apply to tax benefits granted to "noncharities" (for example, business leagues exempt under section 501(c)(6)) because they "are inappropriate objects of taxation and, hence, are not exempt for social policy reasons. Accordingly, these noncharitable mutual benefit organizations that are exempt from income tax do not receive the type of tax benefit that, under tax expenditure theory, is equivalent to a direct grant of government funds." Brennen, Tax Expenditures, supra note 30, at 225-26.

264. Section 501(c)(3) provides that an exempt organization cannot "participate in, or intervene in (including the publishing or distributing of statements), any political 
exempt church conducting business as the Church at Pierce Creek (CPC)-placed a full-page advertisement in two newspapers four days before the 1992 presidential election. ${ }^{265}$ The advertisements urged Christians to vote against the Democratic candidate Bill Clinton because of his "positions on certain moral issues." 266 Each advertisement attributed cosponsorship to CPC and solicited tax-deductible donations in support of its cause. ${ }^{267}$ In response, the IRS invoked a statutorily prescribed church-tax inquiry ${ }^{268}$ followed by a church-tax examination. ${ }^{269}$ Ultimately concluding that the placement of the advertisements violated the statutory prohibition on political-campaign activity, the IRS revoked CPC's section 501(c)(3) tax-exempt status. ${ }^{270}$ CPC challenged the revocation, alleging that the revocation violated its free exercise and free speech rights under the Religious Freedom Restoration Act of 1993 and the First Amendment. ${ }^{271}$

In response to CPC's free exercise claim, the D.C. Circuit found that CPC failed to establish that the revocation had substantially burdened its free exercise rights and that the government lacked a compelling interest justifying such a burden. ${ }^{272}$ The court further concluded that CPC's loss of its exemption for violating the politicalcampaign prohibition did not constitute an unconstitutional burden on its free exercise rights. This would only be true, explained the court,

campaign on behalf of (or in opposition to) any candidate for public office." I.R.C. $\S 501(\mathrm{c})(3)(2000)$.

265. 211 F.3d 137, 139 (D.C. Cir. 2000).

266. Id. Each advertisement displayed the headline "Christians Beware" and declared that Clinton's stances on abortion, homosexuality, and the distribution of condoms to teenage students were contrary to the Bible. Id. at 140 .

267. Id. at 140 .

268. See id. Specific statutory rules govern the IRS's ability to audit churches. See I.R.C. $§ 7611$. A "church tax inquiry" may only be initiated by an appropriate IRS official (typically, a regional commissioner or person of higher rank within the IRS) who "reasonably believes, on the basis of facts and circumstances recorded in writing, that the organization may not qualify for tax exemption as a church" because of certain nonexempt activities. HOPKINS, supra note $55, \S 24.8$, at 711; I.R.C. $\$ 7611$ (a)(I)(A), (2).

269. See Branch Ministries, 211 F.3d at 140; I.R.C. $\$ 7611$ (h)(3).

270. See Branch Ministries, 211 F.3d at 140.

271. Id. at 140-41.

272. See id. at 142 (citing Jimmy Swaggart Ministries v. Bd. of Equalization, 493 U.S. 378, 384-85 (1990) ("[T]he free exercise inquiry asks whether government has placed a substantial burden on the observation of a central religious belief or practice and, if so, whether a compelling governmental interest justifies the burden.")); 42 U.S.C. $\$ 2000$ bb-1(a) to (b) (2000), invalidated by City of Boerne v. Flores, 521 U.S. 507 (1997) (providing that the government can only substantially burden a person's exercise of religion if that burden is "in furtherance of a compelling governmental interest" and "is the least restrictive means of furthering" that interest). 
"if the receipt of the privilege (in this case the tax exemption) is conditioned 'upon conduct proscribed by a religious faith, or ... denie[d] . . . because of conduct mandated by religious belief, thereby putting substantial pressure on an adherent to modify his behavior and to violate his beliefs." "273 The court concluded that the only effect of the revocation would be to "decrease the amount of money available to the Church for its religious practices. The Supreme Court has declared, however, that such a burden 'is not constitutionally significant." 274 Furthermore, the court found that CPC's alleged burden was "overstated" because churches receive "unique treatment" under the Code, thereby rendering the revocation's impact "more symbolic than substantial."275

In relying on Regan, the D.C. Circuit concluded that CPC had "an alternate means of communication" through the formation and operation of an affiliated organization exempt under section 501(c)(4). ${ }^{276}$ The court explained that, while they are subject to a similar ban on political-campaign activities, section 501(c)(4) organizations may form a political-action committee that can participate in political campaigns without limitation. ${ }^{277}$ Still, the court reminded CPC that it could not channel its tax-deductible contributions to fund the political-action committee, because Congress chose not to subsidize such First Amendment activities. ${ }^{278}$

As in Justice Blackmun's concurrence in Regan-which deemed the availability of a section 501(c)(4) organization as an alternate means of communication to be "essential to the constitutionality of section 501(c)(3)'s restrictions on lobbying" ${ }^{279}$ - Branch Ministries relied on

273. Id. (quoting Jimmy Swaggart Ministries, 493 U.S. at 391-92).

274. Id. (quoting Jimmy Swaggart Ministries, 493 U.S. at 391); see also Hernandez v. Comm'r, 490 U.S. 680, 700 (1989) ("[P]etitioners' claimed exemption stems from the contention that an incrementally larger tax burden interferes with their religious activities. This argument knows no limitation.").

275. Branch Ministries, 211 F.3d at 142. The court further explained that, if CPC did not intervene in future political campaigns, "it [could] hold itself out as a 501(c)(3) organization and receive all the benefits of that status. All that [would be] lost, im that event, is the advance assurance of deductibility in the event a donor should be audited." Id. at 142-43.

276. See id. at 143 (citing Regan v. Taxation with Representation of Wash., 461 U.S. 540, 552 (1983)).

277. Id. (citing Treas. Reg. $\S 1.527-6(\mathrm{f})$ to (g) (1980)). The court reminded CPC that the "related [section] 501(c)(4) organization must be separately incorporated; and it must maintain records that will demonstrate that tax-deductible contributions to the Church have not been used to support the political activities conducted by the [section] 501(c)(4) organization's political action arm." Id.

278. Id. at 143-44 (citing Regan, 461 U.S. at 548).

279. Id. at 143 (citing Regan, 461 U.S. at 552-53 (Blackmun, J., concurring)). 
this availability to sustain the constitutionality of section 501(c)(3)'s prohibition on political-campaign activities. ${ }^{280}$ Accordingly, it seems probable that these alternate means of communication might be of similar utility in sustaining the constitutionality of a nondiscrimination requirement in section 501(c)(3). As with the lobbying and politicalcampaign restrictions, a charitable organization would be free to discriminate in the activities conducted within a section 501(c)(4) affiliate without jeopardizing its tax benefits as to its nondiscriminatory activities.

\section{THE NEGATIVE IMPACT ON PLURALISM}

A corresponding criticism of the constitutionality issue is the contention that a nondiscrimination requirement in section 501(c)(3) would effectively stifle open and diverse dialogue on controversial topics like sexual orientation. Specifically, such a requirement would squelch the "pluralism" implicit in the existence and purposes of the nonprofit sector. The Boy Scouts made a similar argument in its brief, stating that "American pluralism thrives on difference [and that] controversial questions of personal morality, often involving religious conviction, are best tested and resolved within the private marketplace of ideas, and not as the subject of government-imposed orthodoxy."281

While it is important to acknowledge the values of pluralism and "autonomy of diverse groups," it is not axiomatic "that these values should always take priority over the effort to break up entrenched patterns of discrimination and include, in socially valued activities, people who have traditionally been outcasts. ${ }^{" 282}$ Because of the negative effects of discrimination on homosexuals, particularly gay youth, any concerted effort to prevent such harm should not be viewed as "a trivial state interest. $" 283$ Furthermore, as demonstrated by Regan and Branch Ministries, a charitable organization like the Boy Scouts can preserve its free speech rights by forming and effectively controlling a section 501(c)(4) social-welfare organization, which would not be subject to a nondiscrimination requirement. ${ }^{284}$

Regardless of which side one takes on the provocative issue of pluralism, the more pertinent question remains whether the government should permit charitable organizations to use the tax-deductible dollars

280. See id. (2000).

281. Brief for Petitioner at 45, 47, Boy Scouts of Am. v. DaIe, 530 U.S. 640

282. KoppeIman, supra note 150 , at 1835 -36 (citations omitted).

283. Id.

284. See supra note 261 and accompanying text. 
they receive to achieve that pluralism at the cost of discriminating against a particular segment of society. ${ }^{285}$ While the nondiscriminationrequirement proposal would create the "gold standard" of tax-exempt status, it does not completely thwart pluralism. Rather, to truly effect pluralism, organizations with discriminatory policies or practices can still retain tax-exempt status under section 501(c)(4) or another applicable subsection of section 501(c); members of these discriminatory organizations would suffer the only cost-the loss of the section 170 charitable-contributions deductions.

\section{APPLICABILITY TO RELIGIOUS ORGANIZATIONS}

Although perplexing, the issue of applying the nondiscriminationrequirement proposal to religious organizations is especially pertinent in that many instances of alleged or actual discrimination by charitable organizations involve church-affiliated or -owned schools, universities, and service providers. ${ }^{286}$ As such, it is crucial to understand the exemption of religious organizations, including churches.

\section{a. Overview of the Religious Exemption}

Section 501(c)(3) provides a tax exemption to an entity organized and operated exclusively for a religious purpose. ${ }^{287}$ Federal income-tax law, however, fails to define the terms "religious" and "religion" in its statutes and regulations, due primarily to First Amendment concerns. ${ }^{288}$ Religious organizations are generally defined more broadly than just "churches" or "traditional houses of worship," and can include book publishers, broadcasters, and cemeteries. ${ }^{289}$ To further complicate matters, the exempt purposes listed in section 501(c)(3) are not "mutually exclusive"; in other words, a "separately incorporated parochial school may be both 'religious' and 'educational,' and many typical 'charitable' activities may be under the control or sponsorship of a particular religion or church." ${ }^{290}$ The IRS is acutely aware of the constitutional ramifications of attempting to define "religion" or

285. See generally Gene SteuerIe, Reform and Equal Justice, 111 TAX Notes 343 (2006) (discussing the promotion of equal justice in tax law and the increased role that both the courts and legislatures should play).

286. See supra notes $14-28$ and accompanying text.

287. See I.R.C. §50I(c)(3) (2000); Treas. Reg. §1.501(c)(3)-1(d)(1)(i)(a) (as amended I990).

288. See Hopkins, supra note 55, $\$ 8.2($ a), at 227.

289. James J. Fishman \& STEPHEN SCHWARZ, NONPRofit ORganizations: CASES AND MATERIALS 444 ( 3 d ed. 2006).

290. Id. at 444-45. 
"religious" narrowly, and has advised its agents to interpret the terms broadly to "encompass . . . even those sects that do not believe in a Supreme Being." ${ }^{291}$ Accordingly, the IRS has subscribed to this general rule: "in the absence of a clear showing that beliefs or doctrines under consideration are not sincerely held by those professing or claiming them as a religion, the Service cannot question the 'religious' nature of those beliefs." ${ }^{292}$ In fact, the IRS has typically demied religiousorganization exemptions on other grounds, such as the section 501(c)(3) private-inurement prohibition ${ }^{293}$ or the section 501(c)(3) lobbying and political-campaign restrictions. ${ }^{294}$

Although it cannot question or regulate religious belief and opinions, Congress can regulate religious action and practices. ${ }^{295}$ In Reynolds v. United States, the Supreme Court upheld a federal law criminalizing the practice of polygamy. ${ }^{296}$ In holding that citizens were not excepted from the statute because of their religious beliefs, the Court explained that, "while [laws] cannot interfere with mere religious belief and opinions, they nıay with practices." ${ }^{297}$ In a subsequent case involving a state statute that regulated solicitation by charitable organizations, the Court elaborated on Reynolds by stating that "the [First] Amendment enibraces two concepts-freedonı to believe and freedonı to act. The first is absolute but, in the nature of things, the

291. Id. at 445; see also I.R.S. Gen. Couns. Mem. 36,993 (Feb. 3, 1977) (finding that a witches' coven qualified as a church under section 501(c)(3)).

292. I.R.S. Gen. Couns. Mem. 36,993 (Feb. 3, 1977); see also Holy Spirit Ass'n for the Umification of World Christianity v. Tax Comm'n, 435 N.E.2d 662, 668 (N.Y. 1982) ("It is for the religious bodies theinselves, rather than the courts or administrative agencies, to define, by their teachings and activities, what their religion is. The courts are obliged to accept such characterization . . . unless it is found to be insincere or [a] sham.").

293. See supra notes 53-57 and accompanying text.

294. See, e.g., Christian Echoes Nat'l Mimistry, Inc. v. United States, 470 F.2d 849 (10th Cir. 1972) (involving the revocation of an organization's exempt status because it failed to ineet the operational test and violated lobbying and politicalcampaign restrictions); Branch Ministries v. Rossotti, 211 F.3d 137 (D.D.C. 2000) (addressing a church's political-campaign-prohibition violation); Unitary Mission Church of Long Island v. Coinm'r, 74 T.C. 507 (1980), aff'd 647 F.2d 163 (2d Cir. 1981) (upholding the demial of a church's exemption because of the private benefit and inurement to the organization's controlling members); see also United States v. Kuch, 288 F. Supp. 439, 444 (D.D.C. 1968) (determining that the organization at issue was not "religious" because it was clearly motivated by the "desire to use drugs and to enjoy drugs for their own sake").

295. FISHMAN \& SCHWARZ, supra note 289, at 453.

296. 98 U.S. 145 (1878).

297. Id. at 166 . 
second cannot be. Conduct remains subject to regulation for the protection of society." 298

Although the same congressional and IRS trepidation with respect to religious belief is present in attempting to define a "church," ${ }^{299}$ some designation is necessary because of the unique treatment and protection that churches receive under the Code. ${ }^{300}$ In making these designations, the IRS follows a fifteen-item checklist ${ }^{301}$-including a distinct legal existence, a recognized creed and form of worship, a formal code of doctrine and discipline, a distinct religious history, and the selection of ordained mimisters after prescribed studies. ${ }^{302}$ Although the IRS has cautioned that these criteria are not exclusive and that it ultimately uses a facts-and-circumstances determination, ${ }^{303}$ the criterion that courts most consistently rely on in determining the existence of a church is the presence or absence of an established and regular congregation ${ }^{304}$ : "In looking for a congregation, the central focus is whether the organization's membership is a coherent group of individuals or families that join together to accomplish religious purposes or shared

298. Cantwell v. Connecticut, 310 U.S. 296, 303-04 (1940). At issue in the case was a state statute that prohibited the solicitation of contributions by religious, charitable, or philanthropic causes without obtaining official approval. See id. at 30102 . The Court ultimately concluded that such approval constituted an invalid prior constraint on the free exercise of religion. See id. at 307.

299. See HoPKINS, supra note $55, \S 8.3$, at 237.

300. See infra notes $308-310$ and accompanying text.

301. See Robert Louthian \& Thomas Miller, 1.R.S., Defining "ChuRCh": THE CONCEPT OF A CONGREGATION 2 (1993), http://www.irs.gov/pub/irs-tege/ eotopica94.pdf. The fifteen points are as follows:

(a) a distinct legal existence, (b) a recognized creed and form of worship,

(c) a definite and distinct ecclesiastical government, (d) a formal code of doctrine and discipline, (e) a distinct religious history, (f) a meinbership not associated with any other church or denomination, $(\mathrm{g})$ an organization of ordained ministers, (h) ordained ministers selected after completing prescribed studies, (i) a literature of its own, (j) established places of worship, (k) regular congregations, (l) regular religious services, (in) Sunday schools for religious instruction of the young, (n) schools for the preparation of its ministers, and (o) any other facts and circuinstances that may bear upon the organization's clain for church status.

Id. In instructing that the criteria "are not exclusive and are not to be mechanically applied," the IRS Chief Counsel recommended the addition of the fifteenth criterion. See Gen. Couns. Mem. 38,982 (May 3, 1983). Federal courts adopted the original fourteen-point test in American Guidance Foundation, Inc. v. United States, 490 F. Supp. 304, 306 n.2 (D.D.C. 1980).

302. LOUTHIAN \& MILLER, supra note 301 , at 2.

303. Id.

304. Id. at 3 ("At a minimun, a church includes a body of believers or communicants that assembles regularly in order to worship." (quoting Am. Guidance Found., 490 F. Supp. at 306)). 
beliefs. The size of the congregation is less important than its dynamic." 305

Although nearly all religious organizations are eligible for a tax exemption under section 501(c)(3), only "churches, their integrated auxiliaries and conventions or associations of churches" are presumed not to be private foundations, ${ }^{306}$ and thus, excepted from the notice requirements of section 508. ${ }^{307}$ That is, a church does not need to file an application for the IRS to recognize it as exempt under section 501(c)(3).$^{308}$ Churches are also relieved from filing annual information returns with the IRS. ${ }^{309}$ In addition, the Internal Revenue Code confers upon churches special procedural safeguards with respect to IRS examinations or audits. ${ }^{310}$ Moreover, churches are exempted from certain rules governing qualified retirement plans, and social security, self-employment, and withholding taxes. ${ }^{311}$

A particular church's activities typically comprise inore than just providing religious services and worship to its congregants. Many churches also operate schools, seminaries, or social-service agencies without creating a separate legal entity. ${ }^{312}$ Until a church makes an activity part of a separate legal entity, the IRS considers it to be a component of the church and therefore covered by the church's exemption. ${ }^{313}$ Once the church forms a new legal entity to conduct an activity, the entity needs to obtain its own tax-exempt status. ${ }^{314}$ Due to the entity's relationship to the church, the Code typically classifies it as an "integrated auxiliary." 115 The $1 R S$ regulations define an "integrated

\section{Id. at 8 .}

306. I.R.C. $\S 508($ b), (c)(1)(A) (2006). An organization that meets the requirements of section 501(c)(3) is classified as either a "public charity" or a "private foundation." See id. \& 509(a). A "public charity" typically receives its income from a broader segment of the general public in the form of gifts, contributions, or receipts from the performance of services, whereas a "private foundation" typically receives contributions from only a few individuals or entities. FISHMAN \& SCHWARZ, supra note 289 , at 751 . Furthermore, private foundations are subject to additional excise taxes. See id. $\S \S 4941-45$.

307. See id. § 508(c)(1). 1995).

308. See id. $\S 508(\mathrm{c})(1)(\mathrm{A})$; Treas. Reg. $\S 1.508-1(\mathrm{a})(3)(\mathrm{i})(\mathrm{a})$ (as amended in

309. See id. § 6033(a)(2)(A)(i).

310. See id. \& 7611 .

311. Nicholas P. Cafardi \& Jaclyn Fabean Cherry, Understanding NONPROFIT AND TAX EXEMPT ORGANIZATIONS $\$ 8.03[\mathrm{Cl}$, at 112 (2006) (citing I.R.C. $\S \S 410(\mathrm{c})(1)(\mathrm{B}), 411(\mathrm{e})(1)(\mathrm{B}), 412(\mathrm{~h})(4), 414(\mathrm{e}), 1402(\mathrm{e}), 3121(\mathrm{~b})(8), 3401(\mathrm{a})(9))$.

312. Id. § 8.06, at 114 .

313. Id.

314. Id.

315. Id. 
auxiliary" as a separate entity that is (1) a charitable organization (for example, a school, mission society, or youth group); (2) a public charity (as opposed to a private foundation) $;^{316}$ (3) internally supported; ${ }^{317}$ and (4) affiliated with a church, convention, or association of churches. ${ }^{318}$ An organization meets the "affiliated" requirement if (1) it is covered by a group exemption letter issued to a church ${ }^{319}$ (2) it is operated, supervised, or controlled by that church; or (3) pertinent facts and circumstances establish such an affiliation. ${ }^{320}$

Under prior regulatory law, an organization had to engage in an activity that was "exclusively religious" to qualify as an integrated auxiliary. ${ }^{321}$ An organization did not meet that standard if its activity "was of a nature other than religious that would serve as a basis for tax exemption"322-for example, educational or scientific activity. The Eighth Circuit, however, has held that this requirement was not consistent with congressional intent, thereby concluding that a socialservice agency could constitute an integrated auxiliary of a church. ${ }^{323}$

316. See supra note 306.

317. An organization is "internally supported" unless it both

(1) offers admissions, goods, services, or facilities for sale, other than on an incidental basis, to the general public (except goods, services, or facilities sold at a nominal charge or for an insubstantial portion of the cost); and (2) normally receives more than 50 percent of its support from a combination of governmental sources, public solicitation of contributions, and receipts from the sale of admissions, goods, performance of services, or furnishing of facilities in activities that are not unrelated trades or businesses.

Treas. Reg. $\S 1.6033-2(\mathrm{~h})(4)$ (as amended in 1995)).

318. See id. $\$ 1.6033-2(\mathrm{~h})(1)$.

319. A group-exemption letter-or "group ruling"-requires the church's central organization to report the entities and affiliates covered by its exemption annually to the IRS and to certify that each meets the requirements for exemption under section 501(c)(3). See CAFARDI \& CHERRY, supra note 311, § 8.05, at 113.

320. HopKINs, supra note $55, \S 8.5$, at 243 (citing Treas. Reg. $\S 1.6033$ $2(\mathrm{~h})(2))$. The regulations provide a nonexclusive list of factors used to determine whether an organization is affiliated: (1) the organization's charter or bylaws reveal that it shares common religious doctrines or practices with a church; (2) such church has the power to appoint, control, or remove at least one of the organization's officers or directors; (3) its name indicates an institutional relationship; and (4) upon dissolution, its assets are to be distributed to such church. Id. (citing Treas. Reg. $\S 1.6033-2(\mathrm{~h})(3)$ ).

321. Id. §8.5, at 244 .

322. Id.

323. See id. $\S 8.5$, at $244-45$ (citing Lutheran Soc. Servs. of Minn. v. United States, 758 F.2d 1283, 1291 (8th Cir. 1985)). 


\section{b. Exception for a "Church"}

There should be an exception for churches from the proposed nondiscrimination requirement, because the proposal's application would likely violate the Free Exercise Clause through the regulation of religious belief. ${ }^{324}$ Furthermore, the proposal does not intend to control what members of churches believe or with whom they share these beliefs. Consequently, an express section 501(c)(3) exception to the nondiscrimination requirement for churches is necessary. ${ }^{325}$ Because the Code's definition of a church also encompasses integrated auxiliaries, it must be tailored to exclude such separate, affiliated entities for purposes of the notice and annual-reporting provisions. Furthermore, to address situations in which a congregational church conducts a school or social-service agency within the same legal entity, Congress should amend the statutory definition of the term "church" in sections 508 and 6033. This amendment should reflect the fifteen-point test, with specific emphasis on the criterion of an established and dynamic congregation. ${ }^{326}$

Such a restricted definition would likely garner criticism from those who believe that there are already too many limitations on churches in the Code. ${ }^{327}$ A more narrow defimition of "church"-for purposes of sections 508 and 6033-however, does not preclude a

324. The First Amendment provides that "Congress shall make no law respecting an establishment of religion, or prohibiting the free exercise thereof." U.S. CONST. amend. I.

325. For example, Congress could further amend the nondiscrimination requirement in section $50 \mathrm{I}(\mathrm{c})(3)$ to include the following subparagraph:

In the case of a church, as defined in section 508(c)(1)(A), this shall not apply to the extent that the application would not be consistent with the church's established tenets or creed.

In addition, Congress should also extend the exception to religious orders and similar exclusively religious organizations exeunpt under section 501(c)(3). Neither the Code nor applicable regulations defme "religious orders." HoPKINS, supra note $55, \S 8.6$, at 245. The IRS, however, has issued guidelines for determining whether an organization qualifies. See Rev. Proc. 91-20, 1991-1 C.B. 524.

326. See supra notes 301-05 and accompanying text.

327. See, e.g., Vaughn E. James, Reaping Where They Have Not Sowed: Have American Churches Failed to Satisfy the Requirements for the Religious Tax Exemption?, 43 CATH. Law. 29, 74 (2004); Ann M. Murphy, Campaign Signs and the Collection Plate-Never the Twain Shall Meet?, 1 PITT. TAX ReV. 35 (2004). Some scholars believe that there are already too inany limitations on churches. See, e.g., Michael Hatfield, Ignore the Rumors-Campaigning from the Pulpit is Okay: Thinking Past the Symbolism of Section S01(c)(3), 20 Notre Dame J.L. ETHICS \& PUB. POL'Y 125 (2006); Christine R. Moore, Religious Tax Exemption and the "Charitable Scrutiny" Test, 15 REGENT U. L. REv. 295 (2003). 
broader definition for other purposes (for instance, the FICA tax provisions). ${ }^{328}$

The Bob Jones University Court, in upholding the imposition of a racial-nondiscrimination policy, appeared to similarly appreciate the difference between a church and a "religious" school by stating that "[w]e deal here only with religious schools-not with churches or other purely religious institutions; here, the governmental interest is in denying public support to racial discrimination in education." ${ }^{329}$ In addition, the Court rejected the university's claim that the denial of its tax exemption violated the Establishment Clause $^{330}$ :

\begin{abstract}
[A] regulation does not violate the Establishment Clause merely because it "happens to coincide or harmonize with the tenets of some or all religions." The IRS policy at issue here is founded on a "neutral, secular basis," and does not violate the Establishment Clause. In addition, as the Court of Appeals noted, "the uniform application of the rule to all religiously operated schools avoids the necessity for a potentially entangling inquiry into whether a racially restrictive practice is the result of sincere religious belief." 331
\end{abstract}

Based on this reasoning, if a section 501(c)(3) nondiscrimination requirement applied to all charitable organizations, other than churches or "other purely religious institutions," 332 it would not violate the Establishment Clause. Rather, the provision would be based on a governmental interest to deny public support to charitable organizations that discriminate. By limiting the scope of the term "church," the requirement could ensure that charitable organizations do not use taxdeductible dollars they receive to discriminate against members of society.

An alternative solution would not require any changes to the current definition and treatment of churches and church-affiliated

328. See I.R.C. $\$ 3121(w)(3)$ (2000). Any amendment to the language of sections 508 and 6033 should be reflected in other Code sections that adopt the "integrated auxiliaries" or "integrated auxiliary" Ianguage. See, e.g., id. $\$ \S 501(\mathrm{~h})(5)(\mathrm{B}), 6043(\mathrm{~b})(1) ; c f$. Charles M. Whelan, "Church" in the Internal Revenue Code: The Definitional Problems, 45 Fordham L. Rev. 885, 887 (1977) (contending that there are too many "church distinctions" in the Code, resulting in "considerable concern and confusion" among church leaders, legal advisors, and the Treasury Department).

329. Bob Jones Univ. v. United States, 461 U.S. 574, 604 n.29 (1983).

330. See id. at 604 n.30.

331. Id.

332. See id. at 604 n.29. 
entities. According to a 1975 Revenue Ruling-issued after the IRS's announcement that schools with racially discriminatory policies would no longer receive tax exemptions ${ }^{333}$-the IRS may use the public-policy doctrine to deny or revoke the exempt status of a church or a separate affiliated entity that operated and controlled a school with a racially discriminatory admissions policy. ${ }^{334}$ In the Ruling, the IRS presented several scenarios, involving (1) school $X$ with a racially discriminatory admissions policy that was incorporated as a separate entity, but affiliated with and controlled by a church; and (2) a school, with the same policy as school $X$, operated directly within the church entity $Y^{335}$

In the first scenario, the IRS held that $X$ was not operated exclusively for charitable purposes (and therefore did not qualify for exempt status under section 501(c)(3)), but this had no effect on the church's exemption. ${ }^{336}$ In the second scenario, the IRS concluded that there should be no disparate result just because the school was operated within $Y$; accordingly, it found that $Y$ was not exempt under section 501(c)(3) ${ }^{337}$ In a third scenario, the IRS similarly denied exempt status to a church that operated both $X$ and $Y$ schools and that used its religious tenets to justify a racially discriminatory policy. ${ }^{338}$ The IRS relied on Reynolds ${ }^{339}$ and subsequent Supreme Court cases that concluded that, although the Free Exercise Clause bars government interference into religious beliefs and opinions, it does not necessarily "affect the legal consequences otherwise attending a given practice or action that is not inherently religious." 340

333. See supra notes $93-95$ and accompanying text.

334. See Rev. Rul. 75-231, 1975-1 C.B. 158 (citing Rev. Rul. 71-447, 1971-2

C.B. 230).

335. See id. at 158.

336. See id. at 159 .

337. See id. The IRS based its conclusion on Norwood v. Harrison, in which the Supreme Court held that a state may not provide free textbooks to a private school if such provision would have a "significant tendency to facilitate, reinforce, and support private discrimination." See id. (citing 413 U.S. 455, 466 (1973)). The Court did not make an exception "for the schools that were not separate legal organizations but were directly operated by churches receiving free textbooks." Id. The IRS concluded that "the legal organization operating $Y$ [in the second scenario was] frustrating Federal public policy by having a racially or ethnically discriminatory policy as to students." Id.

338. See id.

339. See supra notes $295-98$ and accompanying text.

340. Rev. Rul. 75-231, 1975-1 C.B. 158 (citing Reynolds v. United States, 98 U.S. 145, 166-67 (1878); Mitchell v. Pilgrim Holiness Church Corp., 210 F. 2d 879 (7th Cir. 1954)). In the ruling, the IRS explained the following: 
Based on this reasoning, the proposed nondiscrimination requirement could lead to similar conclusions with respect to taxexempt status. Specifically, the imposition of a nondiscrimination requirement on churches and their affiliates would not be unconstitutional, in that the requirement would only address churches' practices or actions, not their religious beliefs or opinions. ${ }^{341}$ To date, however, no federal court has validated the conclusions set forth in the Revenue Ruling.

\section{OTHER POTENTIAL ISSUES}

Another potential difficulty with the nondiscrimination-requirement proposal is how it would apply to same-gender or same-religion organizations, such as an all-girls Catholic high school or an entity directing its relief and educational programs at poverty-stricken Kenyan immigrants. The dilemma of whether the amended section 501(c)(3) would deny tax-exempt status because of this type of discrimination immediately surfaced in the years after Bob Jones University. ${ }^{342}$ The IRS was reluctant to extend the public-policy doctrine to such situations, ${ }^{343}$ in part because the doctrine fails to designate a clear source of public policy. ${ }^{344}$ Perhaps the IRS did not view such instances of discrimination as invidious or harmful, and thus believed they fell outside of the doctrine's intended purposes and goals.

The important distinction between religious belief, on the one hand, and the legal consequences that may validly be attached to action induced by religious belief, on the other, is well illustrated by one recent line of cases interpreting the Federal drug laws. The courts have repeatedly refused to engraft a religious exception on any criminal statute outlawing the transportation of heroin, marijuana, and peyote into the United States, notwithstanding an apparent judicial recognition that a given accused might sincerely believe the use of such drugs has a proper place in certain religious ceremonies which are prescribed in both the Koran and the Bible.

Id. (citing United States v. Spears, 443 F.2d 895 (5th Cir. 197I)).

34I. See supra notes 295-98 and accompanying text (discussing the distinction between religious beliefs and religious practices).

342. FishmAN \& SCHWARZ, supra note 289, at 424.

343. See Rev. Rul. 77-272, I972-2 C.B. 191 (holding that an organization providing job training exclusively for Native Americans did not violate the publicpolicy doctrine because it was formed at the request of the Bureau of Indian Affairs and accomplished goals set forth in the Adult Vocational Training Act); I.R.S. Priv. Ltr. Rul. 77-44-007 (July 28, I977) (ruling that a scholarship fund limiting grants to male graduates at a co-ed high school did not violate the public-policy doctrine because the doctrine did not extent to gender-based discrimination).

344. See supra notes I25-27 and accompanying text. 
Accordingly, the best solution may lie with the statutory definition of "discrimination"-specifically, whether it targets policies or practices that are wrongful, harmful, or invidious. An amendment to section 501(c)(3) should contain a legislative grant to the IRS, along with some clearly defined parameters, which would allow the agency to pronulgate regulations that set forth examples of what constitutes discrimination. For instance, gender-based discrimination might not be deemed to exist in same-sex schools based on other factors such as possible pedagogical benefits and a lack of a concerted effort to specifically exclude the other gender. In addition, national-origin discrimination may be deemed not to exist with respect to an organization whose mission has an established record of combating poverty in an area of a city that happens to be largely comprised of a particular immigrant population. Ultimately, whether or not a particular policy or action constitutes discrimination would depend on a facts-andcircumstances determmation, with standards and burdens of proof borrowed from established federal civil-rights laws and other nondiscrimination statutes. ${ }^{345}$

Two General Counsel Memoranda illustrate this point. In the first memorandum, issued before Bob Jones University, the IRS concluded that a scholarship trust that restricted eligible beneficiaries to Caucasian students furthered racial discrimimation in education, contrary to established federal public policy. ${ }^{346}$ Notwithstanding this conclusion, the IRS doubted that admimistering such a trust would adversely impact the school's exemption because it was de minimis in relation to the school's aggregate scholarship program ${ }^{347}$ In the second memorandum, issued immediately after Bob Jones University, however, the IRS revoked this "per se rule," favoring instead the case-by-case examination of scholarship trusts that restrict eligibility to Caucasian students. ${ }^{348}$ The IRS explained that, for instance, a private trust that grants scholarships only to Caucasian students to enroll at a "predominantly minority school could be said actually to discourage racial discrimination in

345. For example, in McDonnell Douglas v. Green, the Court stated that "[t]he complainant in a Title VII trial inust carry the initial burden under the statute of establishing a prima facie case of racial discrimination." 411 U.S. 792, 802 (1973). To overcome it, the complainant must prove certain facts in order to shift the burden to the prospective einployer "to articulate some legitimate, nondiscriminatory reason for the enuployee's rejection." Id.; see also Hazen Paper Co. v. Biggims, 507 U.S. 604, 609-10 (1993) (discussing the difference between the "disparate treatment" and "disparate impact" theories of employment discrimination in the context of potential enployer liability for age discrinination).

346. See I.R.S. Gen. Couns. Mem. 37,462 (Mar. 17, 1978).

347. See id.

348. See I.R.S. Gen. Couns. Mem. 39,082 (Dec. 1, 1983). 
education." ${ }^{349}$ The IRS further concluded that the "well-established policy of promoting private educational trusts should, on balance, prevail even where the benefits of the trust are limited to members of a particular race." $" 350$ The IRS ultimately found that the school charged with administering the trust adopted and maintained a racialnondiscrimination policy and the trust accounted for a small share of the total financial assistance available to students. ${ }^{351}$

While critics may claim that the nondiscrimination-requirement proposal is unnecessary in light of the numerous state and local nondiscrimination laws, ${ }^{352}$ such laws apply in varying degrees and in limited situations, and may not apply directly to charitable organizations. In addition, such laws are constantly challenged and, therefore, cannot ensure the same comprehensive application to charitable organizations that could be achieved through a section 501(c)(3) amendment. ${ }^{353}$ Although state and local nondiscrimination laws are important and effective in curbing discrimination, they do not prohibit charitable organizations from using the tax-deductible dollars they receive to discriminate against members of society.

\section{CONCLUSION}

A charitable orgamization should not continue to enjoy the benefits of tax-exempt status if it engages in discrimination, because it is intrinsically incoinpatible with a charitable purpose and mission. In filling the current void in federal income-tax law with respect to such discrimination, the nondiscrimination-requirement proposal seeks to transform section 501(c)(3) into the "gold standard" for all tax-exempt organizations, by ensuring that their beneficiaries are as diverse as the taxpaying public from which they draw their support.

By avoiding reliance on the ill-defined public-policy doctrine or on questionably applicable federal civil-rights laws, a nondiscrimination requirement in section 501(c)(3) offers a more comprehensive solution to the problem of discriminatory policies and practices in charitable organizations. It would send a strong message that discrimination is

349. Id.

350. Id.

351. Id.

352. See Lambda Legal, Summary of States, Cities, and Counties Which Prohibit Discrimination Based on Sexual Orientation, http://www.Iambdalegal.org/ourwork/states/ (last visited June 17, 2007).

353. See, e.g., Jonathan Saltzman, Romney Eyes Bill Exempting Religious Groups on Bias Laws, Boston GloBe, Mar. 11, 2006, at A4; Christopher Heredia, Salvation Army Says No Benefits for Partners, S.F. Chron., Nov. 14, 2001, at A22; Milbank, supra note 167. 
fundamentally inconsistent with tax-exempt status and conflicts with society's notion of what constitutes a charity. As the Bob Jones University Court stated, a charitable organization must "be in harmony with the public interest" and its purpose "must not be so at odds with the common commumity conscience as to undermine any public benefit that might otherwise be conferred." 354

This proposal, however, is not completely free from difficulties and challenges. Nevertheless, by permitting discriminatory organizations to qualify as tax-exempt social-welfare organizations under section 501(c)(4), a section 501(c)(3) nondiscrimination requirement should withstand any constitutional challenges and pluralist criticisms. To ensure comprehensive nondiscrimination in light of First Amendment concerns, Congress should consider redefining the term "church" for purposes of the notice and annual-reporting provisions under sections 508 and 6033 of the Code. Tailoring the definition to the fifteen-point test and providing a specific emphasis on the criterion of an established and dynamic congregation would expose the "integrated auxiliaries" of churches to the proposed nondiscrimination requirement. Revisions of section 501(c)(3) should also address the intended meaning of "discrimination" with respect to discriminatory organizations that otherwise operate exclusively for exempt purposes under section 501(c)(3).

In a message to Congress calling for the enactment of Title VI, President John F. Kennedy stated that "[s]imple justice requires that public funds, to which all taxpayers of all races contribute, not be spent in any fashion which encourages, entrenches, subsidizes, or results in racial discrimination." ${ }^{355}$ The inclusion of an expansive nondiscrimination requirement in section $501(c)(3)$ is a necessary step in effectuating this vision.

354. Bob Jones Univ. v. United States, 461 U.S. 574, 592 (1983).

355. 109 CONG. REC. 11,161 (1963). 